\title{
Trends in Orange Juice Consumption and Nutrient Adequacy in Adults 2003-2016
}

\author{
Nicklas $\mathrm{TA}^{1 *}{ }^{*} \mathbf{O}^{\prime} \mathrm{Neil}_{\mathrm{CE}}{ }^{2}$, Saab $\mathrm{R}^{1}$ and Fulgoni VL III ${ }^{3}$ \\ ${ }^{1}$ USDA/ARS Children's Nutrition Research Center, Baylor College of Medicine, \\ Houston, USA \\ ${ }^{2}$ Louisiana State University Agricultural Center (Emeritus), Baton Rouge, USA \\ ${ }^{3}$ Nutrition Impact, Battle Creek, USA \\ *Corresponding Author: Nicklas TA, Professor of Pediatrics, USDA/ARS Children's \\ Nutrition Research Center, Baylor College of Medicine, Houston, Texas, USA.
}

Received: November 25, 2020

Published: December 22, 2020

(C) All rights are reserved by Nicklas TA., et al.

\begin{abstract}
Introduction: No studies have looked at trends in nutrient intakes, orange juice (OJ) consumption and nutrient adequacy in adults overtime.

Methods: The purpose of this study was to examine secular trends and nutrient intakes, OJ consumption, and nutrient adequacy in adults 19 plus years participating in the 2003-2016 National Health and Nutrition Examination Survey.

Results: Approximately $13 \%$ of the total sample consumed OJ with a mean intake of $39.5 \mathrm{~g} / \mathrm{d}$ (76.2 KJ [0.89\% of total energy intake]). Amounts of all 100\% fruit juices consumed decreased and whole fruit intake increased from 2003-2016. Intake of total energy, total carbohydrates, added sugars decreased. Intakes of folate, riboflavin, thiamin, and vitamin $\mathrm{C}$ decreased and intakes of niacin and vitamin B6 increased. Intakes of iron, sodium, and zinc decreased and intake of calcium, magnesium and phosphorus increased. Percentage of adults below the EAR decreased for ten nutrients (i.e. folate, riboflavin, thiamin, vitamins B6, and D, calcium, iron, magnesium, phosphorous and zinc) and the percent above the AI increased for two nutrients (i.e. dietary fiber and sodium) across the deciles of OJ consumption. OJ, other $100 \%$ fruit juices, fruits, breads/rolls/tortillas, and ready-to-eat cereals were major food sources of many nutrients that were consumed at levels below recommendations.

Conclusion: There were changes in intake and nutrient adequacy among adults overtime which varied by OJ consumption. Food patterns varied among consumers and non-consumers suggesting that studies looking at the consumption versus non-consumption of foods need to look at food patterns within the context of the total diet.
\end{abstract}

Keywords: Orange Juice Consumption; 100\% Fruit Juice Consumption; Secular Trends; Nutrient Intake; Nutrient Adequacy; NHANES

\section{Introduction}

In 1924 a team of researchers were contracted by the Florida Citrus Commission to provide better juices for the armed forces and to make more efficient use of the Florida's orange crop. This was prompted by an overproduction of citrus fruits resulting in destruction of $30 \%$ of trees. In the 1930 s the production of orange juice (OJ) exploded, this was due to the industrialization of the US and the use of pasteurization and improved canning processes. By
1986 the growth rate was $32.5 \%$ which has dramatically decreased to $-5.3 \%$ growth rate in 2015 [1]. A possible cause for the dramatic decline in $\mathrm{OJ}$ consumption was a result of consumers's concerns over the sugar content in OJ and not being fully aware of the numerous health benefits of $\mathrm{OJ}$.

There has been an emerging debate among scientists that $100 \%$ fruit juice (FJ) is worse for health than soda due to the sugar content and the type of sugar, namely fructose. Both soda and 100\% FJ 
contain approximately 110 calories and 20-26 grams (g) of sugar per cup [2]. Due to their similar sugar contents, some researchers have started grouping juices and soda together, suggesting that they should be avoided to an equal extent. However, soda and juice are unlikely to affect one's health in the same ways [3]. On average FJ has a fructose concentration of about 45.5 g per liter, only a bit less than the average of $50 \mathrm{~g}$ per liter for sodas [4]. Majority of studies have shown that high sugar consumption has been related to adverse outcomes [5] and that fructose, which is processed entirely in the liver where it is converted to fat, increases the risk for obesity, diabetes, cardiovascular disease and liver disease $[4,6]$. This has led to dietary recommendations to limit the intake of added sugars [7]. However, the assertion that fructose intake is related to adverse health outcomes is not universally accepted. The 2020 Dietary Guidelines Advisory Committee reports [7] that 100\% FJ "can be part of healthy eating patterns;" however, it recommends that at least half the fruit recommendation consumed as whole fruit since that is a better source of fiber than FJ.

One hundred percent fruit juices (FJ) contribute a variety of key vitamins, minerals, and other bioactive compounds to the diet. FJ provides vitamin C, potassium, thiamin, folate, vitamin B6, and magnesium as well as numerous phytochemicals in varying amounts depending on the type of juice $[8,9]$. Several studies have investigated the effects of $100 \% \mathrm{FJ}$ on nutrient intakes [9-14], diet quality $[9,15,16]$, and health status of consumers [9-11,16-19].

Although considerable work has been published regarding $100 \%$ FJ consumption, few studies are available on specific types of $100 \%$ FJ. One study did find that among types of $100 \%$ FJ examined, citrus juices were the most nutrient dense regardless of type of density measures used in the evaluation [8]. OJ is one of the most popular $100 \%$ FJ in the United States. OJ is high in many nutrients, including vitamin $\mathrm{C}$, folate, and potassium. The USDA provides the following information for $250 \mathrm{~mL} 1 \mathrm{cup}$ (8 oz) of OJ: 460 kilojoules (KJ) (110 calories), $2 \mathrm{~g}$ of protein, $26 \mathrm{~g}$ of carbohydrates, and $67 \%$ of the Reference Daily Intake (RDI) for Vitamin C, 15\% for folate, $10 \%$ for potassium, and $6 \%$ for magnesium. Most of the carbohydrates are provided in the form of the naturally occurring sugar fructose [20].

Few studies have looked at the association of OJ consumption on macronutrient intake [21,22], nutrient adequacy [21,23], diet quality and body composition [21,22]. In a critical review [24], the studies confirmed that moderate consumption of $100 \%$ citrus juices, specifically OJ, may provide meaningful nutritional benefits without negatively impacting body weight [24]. With regard to health outcomes, OJ consumption did not adversely affect insulin sensitivity, circulating lipids or body weight in adults [25]. Consumption of OJ was not associated with Type 2 diabetes [26-28], cardiovascular disease [29-31], or risk of gout [32]. Few studies have shown the beneficial effects of 0 J on blood pressure [33,34], bone health [35], cognitive function [36] and with improved biomarkers of health $[17,18]$.

To determine nutrient adequacy, the 2015 DGAC [5] examined the intake distribution for eleven vitamins and nine minerals using nutrient intake data from a representative sample of the U.S population. Data showed that vitamins A, D, E and C, folate, calcium and magnesium were under-consumed relative to the EAR. Potassium and fiber were under-consumed relative to the Adequate Intake (AI). Calcium, potassium, dietary fiber and vitamin D were considered nutrients of public health concern because low intakes were associated with health concerns. Given that OJ, the predominant $100 \%$ FJ consumed, contributed to higher intakes of some of these key nutrients in the diets of adults $[9,21,23,24]$ and per capita consumption has decreased over the past ten years [37], no studies have looked at secular trends in OJ consumption and nutrient adequacy in adults over time. The objective of this study was to examine secular trends in $0 \mathrm{~J}$ consumption along with trends in nutrient adequacy from 2003-2016 in adults 19+ years (y).

\section{Methods}

Study design, subjects, and demographics

Data from the National Health and Nutrition Examination Survey (NHANES) were used to assess dietary intakes of adults aged $19+y$. The NHANES is a cross-sectional survey that uses a complex, multistage, probability sampling procedure to provide nationally representative estimates on the nutritional status of the non-institutionalized US civilian population. Full details of the sampling framework and analytical considerations can be found elsewhere $[38,39]$. Written informed consent was obtained for all participants as described in the NHANES interviewer procedures manual [40]. The NHANES protocols were approved by the National Center for Health Statistics ethics review board [41]. Because this was a secondary data analysis with a lack of personal identifiers, this study was exempted by the Institutional Review Boards associated with the co-authors. 
NHANES 2003-2016 data age $19+\mathrm{y}(\mathrm{n}=40,544)$ was used after exclusions of unreliable data $(n=4,310)$ and pregnant or lactating females $(n=1,164)$; resulting in a total sample of $(n=35,148)$ Sample-weighted data were used in all statistical analyses [39], and all analyses were performed using SAS 9.4 (SAS Institute, Cary, $\mathrm{NC)}$ to adjust the variance for the clustered sample design. Means \pm SEs were determined for nutrient intake and food group consumption for each two year cycle of NHANES from 2003-2016.

To obtain an adequate sample size to produce reliable estimates within this age group, data from seven cycles of NHANES (2003-2016) were combined [42,43]. Most demographic information was collected via interviews using cycle appropriate questionnaires $[44,45]$. Household poverty income ratio (PIR) was classified into three categories: $<1.35,1.35 \leq 1.85$ and $>1.85$. Weight, and height were obtained using the NHANES Anthropometry Procedures Manual [46]. Body mass index (BMI) was calculated as body weight $(\mathrm{kg})$ divided by height $\left(\mathrm{m}^{2}\right)$. Adults with a BMI of 25 to 29.9 and $\geq 30$ were considered overweight or obese, respectively National Heart, Lung, and Blood Institute [47]. Each participant self-reported their race or ethnic group according to pre-defined categories used in the NHANES.

\section{Dietary intake}

An in-person 24-h dietary recall was administered by trained interviewers using an Automated Multiple-Pass Method [40] and a second recall was collected via a telephone interview 3-10 days after the in-person interview. Energy and nutrient intake from foods were determined using respective Food and Nutrient Database for Dietary Studies for each NHANES cycle [48] available from total nutrient intake files. Use of supplements was not included in the analyses. Only recall data judged to be complete and reliable by the National Center for Health Statistics staff were included in these analyses. Detailed descriptions of the dietary recalls and data collection are available in the NHANES Dietary Interviewer's Training Manual [49].

OJ consumption was determined using the OJ food codes in the What We Eat In America (WWEIA): 61210000 (OJ, not further specified; 61210010 OJ freshly squeezed, 61210220 OJ, canned, bottled or in a carton, 61210250 OJ with calcium added, canned, bottled or in a carton, 61210620 OJ, frozen (reconstituted with water), 61210720 OJ, frozen, not reconstituted, 61210820 OJ, frozen, with calcium added (reconstituted with water), 67205000 0J, baby food. Other $100 \%$ juices were defined as other citrus juices other than OJ (food category: 7002), apple juices (food category: 7004), and other juices (food category: 7006).
WWEIA food category classification system was used to classify all foods consumed [50]. Categorization at the subgroup level (n = 48) was used to determine the significant contributors to total nutrient intake. Energy and nutrients from each subgroup of foods were summed across the single 24-h dietary recall for all subjects. Total dietary intakes were obtained by summing intakes across all foods. Sources of energy and nutrients were compared for 20032004 and 2015-2016 among and between OJ consumers and nonconsumers.

Statistical analyses

Usual Intake (UI) of OJ and nutrients was determined using the National Cancer Institute (NCI) method [51]. The NCI macros (Mixtran and Distrib) were used to generate parameter effects after covariate adjustments and to estimate the distribution of UI. The one part NCI model was used for nutrients since these substances are consumed on most days by most subjects. The two part model (frequency and amount) was used for OJ usual intakes. Covariates for these analyses were the day of the week of the 24-h recall [coded as weekend (Friday-Sunday) or weekday (Monday-Thursday)] and sequence of dietary recall (first or second); variance estimates were obtained using the two days of intake with one-day sampling weights. Deciles of OJ consumption were determined based on individual usual intakes with non-consumers in the first decile and consumers of $\mathrm{OJ}$ separated in nine relatively equal intake groups

Mean intakes and standard errors were generated separately for each survey cycle for OJ, FJ, other juices, total fruit, whole fruit, macronutrients, and 15 vitamins and minerals associated with OJ intake. Linear regression coefficients for changes over time from 2003-2016 were generated. Usual nutrient intake distribution were generated for each decile of OJ consumption and nutrient adequacy was determined as percentage below the EAR using the cut-point method [52]. The EAR is the amount of a nutrient that is estimated to meet the requirement for a specific criterion of adequacy of half of the healthy individuals of a specific age, and life stage. Where an EAR was not available the AI cut-points were used to determine the percent at or below a certain level of intake [52]. Regression analyses using the mean OJ consumption of each decile was generated to assess changes across OJ consumption levels. Pvalues for statistical significance were set at $\mathrm{p}<0.05$.

\section{Results}

Demographics of consumers and non-consumers of orange juice (OJ) in adults 19+ y (Table1)

Of the total sample $(n=35,148)$, approximately $13 \%$ reported consuming OJ with an average mean intake (SE) of 39.5 (1.24) g/d 


\begin{tabular}{|c|c|c|c|c|c|c|c|c|c|c|c|c|}
\hline \multirow{2}{*}{ Variables } & \multicolumn{3}{|c|}{ Total Population } & \multicolumn{3}{|c|}{ Non-consumers, $0 \mathrm{~J}$} & \multicolumn{3}{|c|}{ Consumers, $\mathbf{O J}^{1}$} & \multicolumn{3}{|c|}{ Cons vs Non-Cons } \\
\hline & $\mathbf{N}$ & Mean & SE & $\mathbf{N}$ & Mean & SE & $\mathbf{N}$ & Mean & SE & Beta & SE & P value $^{2}$ \\
\hline Orange Juice Cons (\%) & 35,148 & 12.66 & 0.29 & 30,504 & .00 & 0.00 & 4,644 & 100.00 & 0.00 & & & . \\
\hline Age (Years) & 35,148 & 47.01 & 0.25 & 30,504 & 46.51 & 0.24 & 4,644 & 50.50 & 0.50 & 3.99 & 0.44 & $<0.0001$ \\
\hline Gender = Male $(\%)$ & 35,148 & 49.21 & 0.31 & 30,504 & 48.68 & 0.36 & 4,644 & 52.85 & 0.97 & 4.17 & 1.10 & 0.0003 \\
\hline \multicolumn{13}{|c|}{ Ethnicity } \\
\hline Mexican & 35,148 & 8.37 & 0.69 & 30,504 & 8.48 & 0.69 & 4,644 & 7.59 & 0.79 & -0.89 & 0.45 & 0.0541 \\
\hline Other Hispanic (\%) & 35,148 & 4.89 & 0.41 & 30,504 & 4.80 & 0.42 & 4,644 & 5.48 & 0.50 & 0.68 & 0.40 & 0.0908 \\
\hline Non-Hispanic White (\%) & 35,148 & 68.57 & 1.32 & 30,504 & 68.52 & 1.34 & 4,644 & 68.89 & 1.45 & 0.37 & 0.96 & 0.7010 \\
\hline Non-Hispanic Black (\%) & 35,148 & 11.39 & 0.72 & 30,504 & 11.26 & 0.72 & 4,644 & 12.32 & 0.85 & 1.06 & 0.55 & 0.0555 \\
\hline Other (\%) & 35,148 & 6.79 & 0.37 & 30,504 & 6.94 & 0.39 & 4,644 & 5.71 & 0.46 & -1.23 & 0.48 & 0.0125 \\
\hline \multicolumn{13}{|c|}{ Poverty Income Ratio (PIR) ${ }^{3}$} \\
\hline$<1.35(\%)$ & 32,446 & 23.27 & 0.73 & 28,171 & 23.52 & 0.72 & 4,275 & 21.60 & 1.10 & -1.91 & 0.86 & 0.0288 \\
\hline $1.35<=\mathrm{PIR}<=1.85(\%)$ & 32,446 & 9.75 & 0.29 & 28,171 & 9.73 & 0.30 & 4,275 & 9.91 & 0.76 & 0.17 & 0.80 & 0.8283 \\
\hline$>1.85(\%)$ & 32,446 & 66.97 & 0.86 & 28,171 & 66.75 & 0.86 & 4,275 & 68.49 & 1.46 & 1.7 & 1.26 & 0.1691 \\
\hline \multicolumn{13}{|c|}{ Physical Activity } \\
\hline Sedentary & 35,144 & 25.00 & 0.00 & 30,501 & 25.20 & 0.52 & 4,643 & 23.61 & 0.95 & -1.59 & 0.92 & 0.0882 \\
\hline Moderate & 35,144 & 36.16 & 0.40 & 30,501 & 35.95 & 0.40 & 4,643 & 37.64 & 1.14 & 1.69 & 1.13 & 0.1371 \\
\hline Vigorous & 35,144 & 38.83 & 0.62 & 30,501 & 38.85 & 0.62 & 4,643 & 38.74 & 1.34 & -0.10 & 1.25 & 0.9349 \\
\hline \multicolumn{13}{|c|}{ Percent Overweight or Obese ${ }^{4}$} \\
\hline Overweight (\%) & 34,715 & 33.05 & 0.42 & 30,149 & 32.73 & 0.45 & 4,566 & 35.26 & 0.93 & 2.53 & 0.97 & 0.0105 \\
\hline Overweight or Obese (\%) & 34,715 & 68.54 & 0.51 & 30,149 & 68.94 & 0.54 & 4,566 & 65.76 & 0.98 & -3.19 & 1.03 & 0.0025 \\
\hline Obese (\%) & 34,715 & 35.49 & 0.49 & 30,149 & 36.22 & 0.50 & 4,566 & 30.50 & 1.07 & -5.72 & 1.03 & $<0.0001$ \\
\hline Body Mass Index $\left(\mathrm{kg} / \mathrm{m}^{2}\right)$ & 34,715 & 28.74 & 0.08 & 30,149 & 28.87 & 0.08 & 4,566 & 27.85 & 0.13 & -1.02 & 0.12 & $<0.0001$ \\
\hline Kilojoules Consumed (KJ) & 35,148 & 9032 & 34.64 & 30,504 & 8959 & 35.73 & 4,644 & 9536 & 90.33 & 576.35 & 92.63 & $<0.0001$ \\
\hline Grams of Food & 35,148 & 3393.68 & 23.25 & 30,504 & 3400.23 & 24.00 & 4,644 & 3348.51 & 37.64 & -51.72 & 35.82 & 0.1516 \\
\hline
\end{tabular}

Table 1: Demographics of Consumers and Non-consumers of Orange Juice in Adults (NHANES 2003-2016).

${ }^{1}$ Orange juice consumption, in grams, was determined using all orange juice food codes from the What We Eat in America; consumers were defined as having any consumption of orange juice in the 24 hour dietary recalls

${ }^{2}$ Significance was defined as $\mathrm{p}<0.05$

${ }^{3}$ Self-reported through the National Health And Nutrition Examination Survey questionnaire

${ }^{4} \mathrm{In}$ adults, a BMI between $25 \mathrm{~kg} / \mathrm{m}^{2}$ and $29.9 \mathrm{~kg} / \mathrm{m}^{2}$ is considered overweight; and a BMI of $30 \mathrm{~kg} / \mathrm{m}^{2}$ or higher is considered obese

(1.3fl oz), which was equivalent to 76.1(2.4) KJ (18.2 (0.57) Kcal) or $0.89(0.03) \%$ of total energy intake. OJ consumers were more likely to be older ( $p=<0.0001)$, male $(p=0.0003)$ and less likely to have a PIR $<1.35 \%(p=0.0288)$ and to be obese $(p=<0.0001)$, or overweight or obese combined. However, the per- cent of adults overweight was significantly higher among OJ consumers ( $\mathrm{p}=$ 0.0105); yet, mean BMI was lower ( $p=<0.0001$ ) compared to non-consumers. OJ consumers consumed more total KJ than nonconsumers $(\mathrm{p}=<0.0001)$.

Linear trends in fruits and nutrient intakes among adults from NHANES 2003-2016 (Table 2)

- Fruits: Although there was no significant trend over time in consumption of total fruits, there was an increase in con- sumption of whole fruits ( $\beta=0.02$ cup eq $/$ cycle, $p=<0.0001$ ) and a decrease in consumption of FJ $(\beta=-0.02 \mathrm{~g} /$ cycle, $\mathrm{p}=$ $0.0044)$, specifically for both $0 \mathrm{~J}(\beta=-3.93 \mathrm{~g} /$ cycle, $\mathrm{p}=<0.0001$ and $100 \%$ other juices $(\beta=-1.46 \mathrm{~g} /$ cycle, $\mathrm{p}=0.0368)$.

- Macronutrients: Total energy intake $(\mathrm{KJ})$ decreased from 2003-2016 ( $\beta=-54 \mathrm{KJ} /$ cycle, $\mathrm{p}=0.0013)$. This was reflected in a decreased intake of carbohydrate $(\beta=-3.06 \mathrm{~g} / \mathrm{cycle}, \mathrm{p}=$ $<0.0001)$ and total sugars $(\beta=-2.91 \mathrm{~g} /$ cycle, $p=<0.0001)$, specifically added sugars $(\beta=-0.59 \mathrm{~g} /$ cycle, $\mathrm{p}=<0.0001)$. Total fiber intake increased ( $\beta=0.34 \mathrm{~g} /$ cycle, $\mathrm{p}=<0.0001$ ). There was no significant trend in intakes of total protein, total fat and saturated fat. 


\begin{tabular}{|c|c|c|c|c|c|c|c|c|c|c|c|c|c|c|c|c|c|}
\hline \multirow[b]{2}{*}{ Variable } & \multicolumn{2}{|c|}{ 2003-2004 } & \multicolumn{2}{|c|}{ 2005-2006 } & \multicolumn{2}{|c|}{ 2007-2008 } & \multicolumn{2}{|c|}{ 2009-2010 } & \multicolumn{2}{|c|}{ 2011-2012 } & \multicolumn{2}{|c|}{$2013-2014$} & \multicolumn{2}{|c|}{$2015-2016$} & \multicolumn{3}{|c|}{ Linear Trend } \\
\hline & Mean & SE & Mean & SE & Mean & SE & Mean & $\mathbf{E}$ & Mean & SE & Mean & SE & Mean & SE & Beta $^{3}$ & SE & P value $^{4}$ \\
\hline $\begin{array}{r}\text { Total f } \\
\text { (cup }\end{array}$ & 0.93 & 0.05 & 0.93 & 0.04 & 96 & 0.04 & 07 & 0.02 & 0.97 & 0.04 & .89 & 0.03 & .92 & 0.04 & 0.00 & 0.01 & 0.6576 \\
\hline $\begin{array}{r}\text { Whole } \\
\text { (cup }\end{array}$ & & 0.03 & & & & 3 & & .02 & 7 & 0.02 & 5 & 0.03 & 59 & 0.04 & 0.02 & .01 & $<0.0001$ \\
\hline $\begin{array}{l}\text { Fruit ju } \\
\text { (cup }\end{array}$ & & 0.03 & & & & 2 & & 1 & & 0 & & 1 & & 0.01 & -0.02 & .00 & .0044 \\
\hline $\begin{array}{l}\text { Orange Juice } \\
\text { (g) }\end{array}$ & 52.00 & 02 & 50.90 & 53 & 3 & 52 & 6 & .52 & 7 & 5.03 & 6 & 1.86 & 30.10 & 2.20 & -3.93 & 0.60 & $<0.0001$ \\
\hline $\begin{array}{c}\text { Other } 1 \\
\text { Juice }\end{array}$ & 5 & 4.88 & .38 & 3.59 & 34.48 & 2.36 & 7 & 2.63 & 6 & 4.34 & & 1.75 & & 2.66 & -1.46 & 69 & 68 \\
\hline $\begin{array}{l}\text { Total Energy } \\
\text { (KJ) }\end{array}$ & 9 & 67 & 9 & & 8 & & 8 & 4 & 9209 & 5 & & 75 & & 88 & -54 & 7 & 13 \\
\hline Protei & 82.87 & 1.12 & 85.46 & 1.32 & 81.56 & 1.20 & 83.10 & 0.99 & 83.45 & 0.69 & 83.65 & 0.72 & 82.39 & 1.22 & -0.11 & 0.22 & 0.6024 \\
\hline $\begin{array}{r}\text { Carbohyc } \\
\text { (g) }\end{array}$ & 269.69 & 2.44 & 261.57 & 4.14 & 256.55 & 3.12 & 259.37 & 2.24 & 266.90 & 2.08 & 252.74 & 2.14 & 243.82 & 2.48 & -3.06 & 0.51 & $<0.0001$ \\
\hline Total sugars $(\mathrm{g})$ & 127.26 & 1.68 & 119.37 & 2.58 & 117.48 & 2.51 & 117.09 & 1.27 & 117.71 & 1.36 & 111.41 & 1.37 & 105.38 & 1.70 & -2.91 & 0.35 & $<0.0001$ \\
\hline $\begin{array}{c}\text { Added sugars } \\
\text { (g) }\end{array}$ & 20.87 & 0.48 & 18.81 & 0.58 & 18.71 & 0.72 & 17.95 & 0.33 & 18.34 & 0.40 & 17.61 & 0.38 & 16.25 & 0.42 & -0.59 & 0.09 & $<0.0001$ \\
\hline Total fat (g) & 8 & S & & 1 & & 1 & & 1 & & 0.73 & & 0.83 & & 1.14 & 0.02 & 21 & .9356 \\
\hline $\begin{array}{r}\text { Saturat } \\
\text { (g) }\end{array}$ & 27.61 & 0.33 & 28.12 & 0.59 & 26.83 & 0.51 & 5.97 & 0.41 & 26.62 & 0.37 & 26.73 & 0.27 & 27.49 & 0.47 & -0.11 & 0.08 & 314 \\
\hline $\begin{array}{r}\text { Dietary } \\
\text { (g } \\
\end{array}$ & & 0.36 & & & & 19 & & 0.24 & & 0.33 & & 0.26 & & 0.38 & 0.34 & .07 & \\
\hline $\begin{array}{l}\text { Folate, } \\
\qquad \mu \varepsilon\end{array}$ & .44 & 10.32 & 540.10 & 7.79 & 79 & 12.88 & 25 & 7.30 & 77 & 8.96 & 87 & 8.29 & 16 & 9.41 & -2.53 & 1.79 & 601 \\
\hline Niacin (mg) & 44 & 0.33 & 26.06 & & 95 & & 92 & 0.30 & & & 56 & 0.24 & 26.14 & 0.52 & 0.26 & 08 & 012 \\
\hline $\begin{array}{l}\text { Riboflavin } \\
\text { (mg) }\end{array}$ & זר & 0.04 & 2.30 & 0.04 & 0 & 0.05 & 2.16 & 0.03 & 2 & 0.03 & 8 & 0.03 & 2.16 & 0.04 & -0.02 & 0.01 & 156 \\
\hline Thiar & & 0.02 & 1.70 & 0.05 & & 0.03 & 1.00 & 0.02 & 1.00 & 0.02 & & 0.02 & 1.58 & 0.02 & -0.01 & 0.00 & 014 \\
\hline $\begin{array}{c}\text { Vitamin A, RAE } \\
(\mu \mathrm{g})\end{array}$ & 597.35 & 15.67 & 627.24 & 15.76 & 611.02 & 15.84 & 638.55 & 12.00 & 672.82 & 37.98 & 635.59 & 12.34 & 626.38 & 13.39 & 5.71 & 2.96 & 561 \\
\hline $\begin{array}{c}\text { Vitamin B6 } \\
(\mathrm{mg})\end{array}$ & 1.86 & 0.03 & 04 & 04 & 1.97 & 04 & 1 & 03 & 0 & 0.04 & 1 & 0.03 & 4 & 0.05 & 0.05 & 0.01 & 1 \\
\hline Vitamin C (mg) & 00.09 & 3.50 & 00.94 & 2.20 & & & & 1.71 & & 3.70 & 78.48 & 1.66 & 79.26 & 2.56 & -1.44 & 53 & .0082 \\
\hline $\begin{array}{c}\text { Vitamin D (D2 } \\
+\mathrm{D} 3)(\mu \mathrm{g})\end{array}$ & 4.49 & 0.17 & 4.59 & 0.12 & 4.34 & 0.12 & 5.13 & 0.14 & 4.70 & 0.14 & 4.74 & 0.15 & 4.64 & 0.14 & 0.04 & 0.03 & 0.1666 \\
\hline Calcium (mg) & 877.0 & 17.0 & 954.0 & 19.0 & 933.0 & 22.0 & 1016.0 & 11.0 & 995.0 & 15.0 & 965.0 & 12.0 & 948.0 & 19.0 & 10.0 & 3.0 & 0.0024 \\
\hline Iron (mg) & 15.72 & 0.18 & 6.18 & 0.20 & 15.14 & 0.32 & 15.24 & 0.15 & 15.77 & 0.16 & 14.55 & 0.13 & 13.97 & 0.16 & -0.29 & 0.03 & $<0.0001$ \\
\hline $\begin{array}{l}\text { Magnesium } \\
(\mathrm{mg})\end{array}$ & 280.12 & 4.44 & 303.85 & 4.44 & 293.63 & 6.91 & 306.35 & 2.91 & 313.93 & 4.70 & 304.70 & 3.29 & 305.44 & 5.26 & 3.41 & 0.91 & 0.0003 \\
\hline $\begin{array}{l}\text { Phosphorus } \\
\text { (mg) }\end{array}$ & 1331.43 & 17.55 & 1362.29 & 20.86 & 1328.72 & 23.26 & 1415.45 & 14.48 & 1424.99 & 11.44 & 1398.81 & 12.09 & 1383.46 & 21.62 & 11.37 & 3.54 & 0.0017 \\
\hline $\begin{array}{l}\text { Potassium } \\
\text { (mg) }\end{array}$ & 2720.72 & 35.46 & 2744.67 & 35.54 & 2634.96 & 49.60 & 2774.67 & 24.85 & 2792.92 & 35.59 & 2653.62 & 30.29 & 2626.48 & 38.89 & -11.40 & 6.92 & 22 \\
\hline Sodium (mg) & 3624.66 & 33.77 & 3692.93 & 51.05 & 3591.95 & 57.97 & 3594.55 & 31.06 & 3615.72 & 25.77 & 3528.74 & 31.02 & 3537.45 & 41.18 & -20.33 & 7.55 & 0.0082 \\
\hline Zinc (mg) & 12.05 & 0.20 & 12.84 & 0.23 & 12.04 & 0.26 & 11.97 & 0.16 & 11.57 & 0.13 & 11.19 & 0.09 & 11.21 & 0.19 & -0.23 & 0.04 & $<0.0001$ \\
\hline
\end{tabular}

Table 2: Linear Trends in Fruits ${ }^{1}$ and Nutrient Intakes ${ }^{2}$ among Adults (19+) from NHANES 2003 to 2016.

${ }^{1}$ Intake of fruits was determined using food codes from the What We Eat In America.

${ }^{2}$ Usual Intake (UI) of nutrients was determined using the National Cancer Institute Method

${ }^{3}$ Linear regression coefficients were generated to access changes over time (2003-2016).

${ }^{4}$ Significance was defined as $\mathrm{p}<0.05$. 
- Vitamins: There was a significant decrease in intakes of folate $(\beta=-2.64 \mu \mathrm{g} /$ cycle, $\mathrm{p}=0.0015$, riboflavin $(\beta=-0.02 \mathrm{mg} / \mathrm{cycle}$, $\mathrm{p}=0.0156)$, thiamin $(\beta=-0.01 \mathrm{mg} / \mathrm{cycle}, \mathrm{p}<0.0014)$, and vitamin $C(\beta=-1.44 \mathrm{mg} / \mathrm{cycle}, \mathrm{p}<0.01)$. In contrast, intakes of niacin $(\beta=0.26 \mathrm{mg} /$ cycle, $\mathrm{p}<0.0012)$ and vitamin $\mathrm{B} 6(\beta=$ $0.05 \mathrm{mg} /$ cycle, $\mathrm{p}=<0.0001$ ) increased.
- Minerals: Intakes of iron $(\beta=-0.29 \mathrm{mg} / \mathrm{cycle}, \mathrm{p}=<0.0001)$, sodium $(\beta=$ $-20.33 \mathrm{mg} /$ cycle, $\mathrm{p}=0.0082)$ and zinc $(\beta=-0.23 \mathrm{mg} /$ cycle, $\mathrm{p}=<0.0001)$ decreased from 2003-2016. In contrast, intakes of calcium $(\beta=10.0$ $\mathrm{mg} /$ cycle, $\mathrm{p}=0.0024)$, magnesium $(\beta=3.41 \mathrm{mg} /$ cycle, $\mathrm{p}=0.0003)$ and phosphorus $(\beta=11.37 \mathrm{mg} /$ cycle, $\mathrm{p}=0.0017)$ increased.

Linear trends in nutrient adequacy among adults from NHANES 20032016 (Table 3)

\begin{tabular}{|c|c|c|c|c|c|c|c|c|c|c|c|c|c|c|c|c|c|c|}
\hline \multirow[b]{2}{*}{ Variable $^{1}$} & \multirow{2}{*}{$\begin{array}{c}\text { Cutoff } \\
\%^{2}\end{array}$} & \multicolumn{2}{|c|}{ 2003-2004 } & \multicolumn{2}{|c|}{ 2005-2006 } & \multicolumn{2}{|c|}{$2007-2008$} & \multicolumn{2}{|c|}{ 2009-2010 } & \multicolumn{2}{|c|}{ 2011-2012 } & \multicolumn{2}{|c|}{$2013-2014$} & \multicolumn{2}{|c|}{$\begin{array}{c}2015- \\
2016\end{array}$} & \multicolumn{3}{|c|}{ Linear Trend } \\
\hline & & & SE & Mean & $\mathbf{S}$ & & SE & N & SE & $\mathbf{M}$ & SE & n & SE & Mean & SE & 1 & SE & $\begin{array}{c}P \\
\text { alue }\end{array}$ \\
\hline & & & & & & & & & & & & & 39 & & 0.34 & & & \\
\hline Carb & & & & & & & 23 & 10 & .11 & & .16 & & .21 & 15 & 0.30 & .00 & .06 & 年 \\
\hline Dieta & & & & & & & 8 & & 6 & & 5 & & 32 & 7 & .06 & 91 & 20 & 01 \\
\hline & & & & & & & 0 & & 0.38 & & 19 & & 19 & 99 & 0.44 & - & 13 & 59 \\
\hline $\begin{array}{r}\text { hiam } \\
\mathrm{B} \\
\end{array}$ & r & 06 & & & & & & & & & (1.18 & & & & 6 & 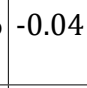 & & \\
\hline Vitam & & & & & & & & & 1.95 & & 2.74 & & 1.44 & 92 & 1.82 & -0.96 & 0.42 & ( \\
\hline Vitam & & .01 & & & & & 1.99 & 22 & 1.09 & & 0.73 & & 0.77 & 13.19 & 1.32 & -0.73 & 0.59 & 2660 \\
\hline Vita & & 2 & 2 & 2.91 & 9 & 5 & 0 & 9 & 1.41 & 7 & 1.85 & 3 & 1.72 & 35 & 2.21 & 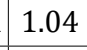 & 54 & 0.1121 \\
\hline $\begin{array}{r}\text { Vitam } \\
\text { D3 } \\
\end{array}$ & & 95.80 & & & & & 5 & & 0.95 & & 52 & 3 & 0.79 & 95.66 & 0.64 & -0.03 & 14 & ( \\
\hline Calci & & .47 & & .78 & 1.45 & 46.44 & 2.25 & 38.30 & 0.95 & 41.49 & 1.35 & 43.91 & 1.24 & 45.14 & 1.48 & -0.95 & .00 & 3875 \\
\hline & th & 486 & 0.30 & & .35 & 工 & 0.72 & 63 & 0.37 & 06 & 0.35 & 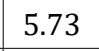 & 0.39 & 5.17 & 0.51 & 0.12 & .13 & 0.3701 \\
\hline & & & & & & & 3.09 & & 1.10 & & 1.55 & & 1.26 & 53.34 & 1.83 & -1.40 & .72 & 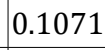 \\
\hline Phos & & & & & 0.39 & & 0.50 & 42 & 0.13 & & 0.13 & 72 & 0.21 & 0.79 & 0.20 & -0.11 & 0.11 & 543 \\
\hline Potassium ( & I 00 & 3.42 & 1.66 & 4.46 & 1.16 & 30.09 & 2.19 & 36.40 & 1.32 & 36.82 & 1.50 & 30.26 & 1.39 & 29.55 & 1.59 & -0.58 & .57 & 0.3562 \\
\hline $\begin{array}{c}\text { Riboflavin } \\
\text { Vitamin B2) (mg) }\end{array}$ & EAR & 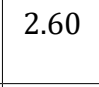 & 48 & 71 & 0 & .58 & 0.46 & 2.56 & 0.35 & 61 & 0.39 & 23 & 54 & 3.14 & 0.35 & 0.09 & 0.04 & c \\
\hline Sodiu & (70 novere) & 9.10 & .55 & .02 & 0.20 & 99.16 & 0.36 & 99.54 & 0.24 & 99.67 & 0.08 & 99.20 & 0.22 & 98.90 & 0.22 & 0.04 & 0.09 & $0.00 / 0$ \\
\hline $\mathrm{nc}(\mathrm{mg})$ & EAR (\% Below) & 3.39 & 1.37 & 0.97 & 0.94 & 12.93 & 1.93 & 13.12 & 1.31 & 14.59 & 1.60 & 18.95 & 1.61 & 17.13 & 1.40 & 1.07 & 0.32 & 0.0203 \\
\hline
\end{tabular}

Table 3: Linear Trends in percent below the Estimated Average Requirement (EAR) or percent above

the Adequate Intake (AI) among adults from NHANES 2003-2016.

${ }^{1}$ Usual Intake (UI) of nutrients was determined using the National Cancer Institute Method

${ }^{2}$ Nutrient adequacy was determined based on the percent below the Estimated Average Requirement (EAR) or above the Adequate Intake (AI)

${ }^{3}$ Linear regression coefficients were generated to access changes over time (2003-2016)

${ }^{4}$ Significance was defined as $\mathrm{p}<0.05$.

The percentage of adults above the AI for dietary fiber increased $(\beta=0.91 \mathrm{~g} /$ cycle, $\mathrm{p}=0.0061)$ and the percentage below the EAR for zinc increased $(\beta=1.07 \mathrm{mg} / \mathrm{cycle}, \mathrm{p}=0.0203)$. No significant trend in nutrient adequacy were found among the other nutrients studied.

Percent below EAR or above AI by decile of OJ consumption

Deciles of $\mathrm{OJ}$ consumption were determined based on dietary intake data with non-consumers in the first decile and consumers of $\mathrm{OJ}$ separated into nine relatively equal groups; mean OJ consumptions of decile 1 , decile 5 and decile 10 were 0.216 , and $788 \mathrm{~g} / \mathrm{d}$. All regression coefficients for assessing change in percentage below the EAR/above the AI across deciles of $\mathrm{OJ}$ consumption are presented in supplemental table 1.

- Folate: For every gram of OJ consumed the percent of the population with inadequate intake of folate decreased 0.02 percentage units (Figure 1). In other words, for every $120 \mathrm{~g} \mathrm{(} 4 \mathrm{fl} \mathrm{oz}$ ) of OJ consumed the percent of the population with inadequate intake decreased 2.4 percentage points. 


\begin{tabular}{|c|c|c|c|}
\hline Nutrients with an EAR & Beta & SE & p-value \\
\hline Calcium & -0.06 & 0.01 & 0.0001 \\
\hline Folate, DFE & -0.02 & 0.003 & 0.0014 \\
\hline Iron & -0.005 & 0.002 & 0.0238 \\
\hline Magnesium & -0.05 & 0.004 & $<0.0001$ \\
\hline Niacin & -0.002 & 0.001 & 0.0645 \\
\hline Phosphorus & -0.002 & 0.001 & 0.0228 \\
\hline Riboflavin & -0.004 & 0.002 & 0.0235 \\
\hline Thiamin & -0.01 & 0.002 & 0.0090 \\
\hline Vitamin A & -0.01 & 0.01 & 0.0943 \\
\hline Vitamin B6 & -0.01 & 0.003 & 0.0005 \\
\hline Vitamin C & -0.0001 & 0.001 & 0.9137 \\
\hline Vitamin D & -0.01 & 0.004 & 0.0165 \\
\hline Zinc & -0.01 & 0.002 & 0.0021 \\
\hline Nutrients with an AI & & & \\
\hline Dietary Fiber & 0.004 & 0.002 & 0.0260 \\
\hline Potassium & 0.01 & 0.01 & 0.4425 \\
\hline Sodium & 0.001 & 0.0003 & 0.0158 \\
\hline
\end{tabular}

Supplemental Table 1: Regression coefficient for assessing change in \% below the EAR/above the $\mathrm{AI}^{*}$ across deciles of orange juice consumption-Adults 19+ years.

*EAR: Estimated Average Requirement; AI: Adequate Intake.

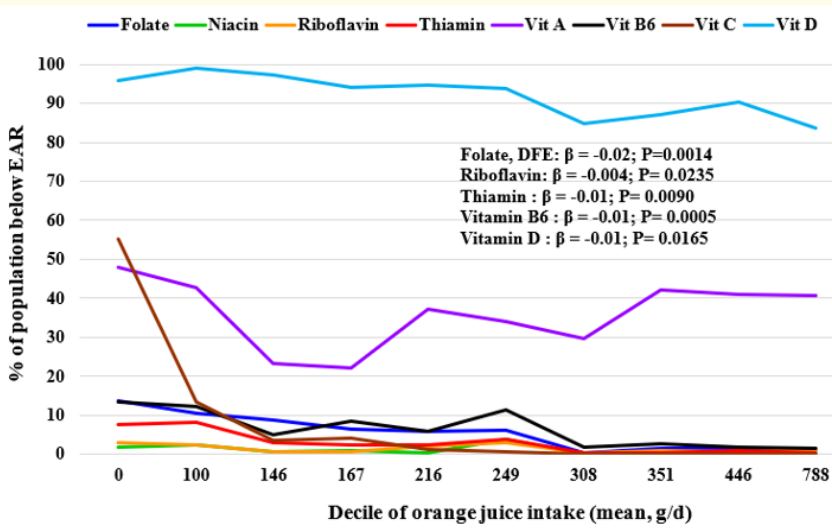

Figure 1: Percentage of Adults 19+y (National Health And Nutrition Examination Survey 2003-2016) with Intakes Below the Estimated Average Requirement (EAR) for Select Vitamins by Decile of Orange Juice (OJ) Consumption. Regression Analysis

(ß: regression coefficient) was Used to Assess if a Linear Association Existed with OJ Consumption. Only Associations Significant at $\mathrm{p}<0.05$ are Presented.

- Riboflavin: For every gram of OJ consumed the percent of the population with inadequate intake of riboflavin decreased 0.004 percentage units (Figure 1). In other words, for every $120 \mathrm{~g} \mathrm{(} 4 \mathrm{fl} \mathrm{oz}$ ) of OJ consumed the percent of the population with inadequate intake decreased 0.48 percentage points.
- Thiamin, vitamins B6 and D: For all three vitamins, for every gram of $\mathrm{OJ}$ consumed the percent of the population with inadequate intake of all three vitamins: decreased 0.01 percentage units (Figure 1). In other words, for every 120g (4 $\mathrm{fl} \mathrm{oz}$ ) of $\mathrm{OJ}$ consumed the percent of the population with inadequate intake of each of the three vitamins decreased 1.2 percentage points.

- Calcium: For every gram of OJ consumed, the percent of the population with inadequate intake of calcium decreased 0.06 percentage units (Figure 2). In other words, for every $120 \mathrm{~g}$ ( $4 \mathrm{fl} \mathrm{oz}$ ) of $\mathrm{O}$ consumed the percent of the population with inadequate intake decreased 7.2 percentage points.

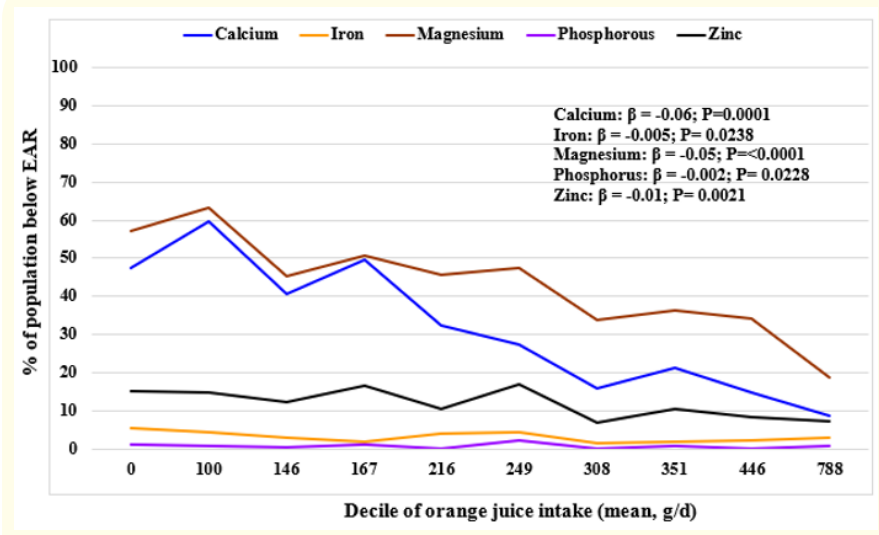

Figure 2: Percentage of Adults 19+y (National Health And Nutrition Examination Survey 2003-2016) with Intakes Below the Estimated Average Requirement (EAR) for Select Minerals by Decile of Orange Juice (OJ) Consumption. Regression Analysis

ß: regression coefficient) was Used to Assess if a Linear Association Existed with OJ Consumption. Only Associations Significant at $\mathrm{p}<0.05$ are Presented.

- Phosphorus: For every gram of OJ consumed the percent of the population with inadequate intake of phosphorus decreased 0.002 percentage units (Figure 2). In other words, for every $120 \mathrm{~g} \mathrm{(} 4 \mathrm{fl} \mathrm{oz}$ ) of $\mathrm{OJ}$ consumed the percent of the population with inadequate intake decreased 0.24 percentage points.

- Zinc: For every gram of OJ consumed the percent of the population with inadequate intake of zinc decreased 0.01 percent-

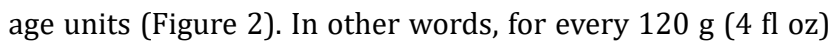
of $\mathrm{OJ}$ consumed the percent of the population with inadequate intake decreased 1.2 percentage points.

- Dietary Fiber: For every gram of OJ consumed the percent of the population above the AI for dietary fiber increased 0.004

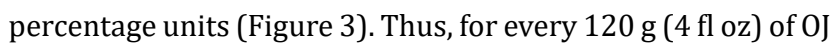
consumed the percent of the population with adequate intake increased 0.48 percentage units. 


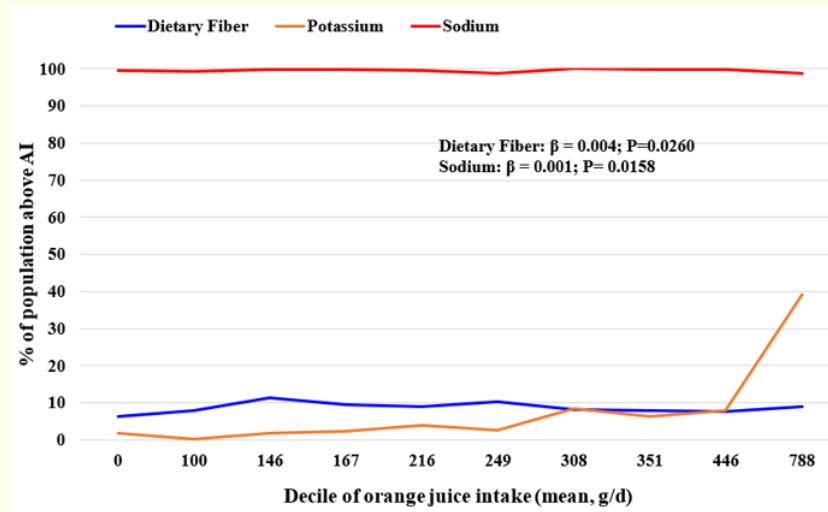

Figure 3: Percentage of Adults 19+y (National Health And Nutrition Examination Survey 2003-2016) with Intakes Above Adequate Intake (AI) of Orange Juice (OJ) Consumption. Regression Analysis ( $ß$ : regression coefficient) was Used to Assess if a Linear Association Existed with OJ Consumption. Only Associations Significant at $\mathrm{p}<0.05$ are Presented.
- Sodium: For every gram of OJ consumed the percent of the population above the AI for sodium increased 0.001 percent units (Figure 3). Thus, for every $120 \mathrm{~g} \mathrm{(} 4 \mathrm{fl} \mathrm{oz}$ ) of OJ consumed the percent of the population with adequate intake increased 0.12 percentage units. For other nutrients evaluated (Supplemental Table 1) there were no significant associations of changes in the percentage of the population below the EAR/ above the $\mathrm{AI}$ across deciles of $\mathrm{OJ}$ intake.

Major food sources of energy and nutrient intake by orange juice consumption and survey year

- Energy: The food sources of energy intake by OJ consumption that were significantly different for NHANES survey years 2003-2004 and 2015-2016 are presented in table 4. Only the food sources of energy intake that were significantly different among $0 \mathrm{~J}$ consumers and non-consumers are presented. Of the increased energy in 2003-2004 among OJ consumers (593 KJ) as compared to non-consumers, mostly was due to consumption of $\mathrm{OJ}(556 \mathrm{KJ})$ and other $100 \%$ juices (554 KJ),

\begin{tabular}{|c|c|c|c|c|c|c|c|}
\hline \multirow{3}{*}{ Significant food groups ${ }^{1}$} & \multicolumn{7}{|c|}{ 2003-2004 Energy Intake (KJ) of Adults 19+ Years of Age } \\
\hline & \multicolumn{2}{|c|}{ OJ consumers } & \multicolumn{2}{|c|}{ OJ non-consumers ${ }^{2}$} & \multicolumn{3}{|c|}{ OJ consumers vs $0 \mathrm{~J}$ non-consumers } \\
\hline & Mean & SE & Mean & SE & Beta $^{3}$ & SE & P value $^{4}$ \\
\hline All Foods & 9775 & 178.78 & 9182 & 75.10 & 593.50 & 195.56 & 0.0084 \\
\hline Orange Juice & 556 & 20.92 & 0 & 0.00 & 555.55 & 20.92 & $<0.0001$ \\
\hline Fruits & 294 & 20.38 & 170 & 9.00 & 123.39 & 19.62 & $<0.0001$ \\
\hline 100\% Juice & 618 & 31.25 & 64 & 12.01 & 554.05 & 31.05 & $<0.0001$ \\
\hline Sweetened Beverages & 593 & 50.46 & 777 & 31.30 & -184.26 & 46.48 & 0.0012 \\
\hline Diet Beverages & 6 & 0.79 & 11 & 1.38 & -4.81 & 1.38 & 0.0032 \\
\hline Meats & 283 & 27.36 & 358 & 24.27 & -74.73 & 28.87 & 0.0205 \\
\hline Breads, Rolls, Tortillas & 737 & 47.11 & 628 & 23.89 & 109.45 & 44.56 & 0.0267 \\
\hline Mixed Dishes - Mexican & 116 & 22.38 & 247 & 52.51 & -130.16 & 58.91 & 0.0432 \\
\hline \multicolumn{8}{|c|}{ 2015-2016 Energy Intake (KJ) of Adults 19+ Years of Age } \\
\hline All Foods & 9663 & 249.41 & 8704 & 98.28 & 958.47 & 278.36 & 0.0036 \\
\hline Orange Juice & 598 & 24.06 & 0 & 0.00 & 597.77 & 24.06 & $<0.0001$ \\
\hline $100 \%$ Juice & 645 & 26.28 & 43 & 5.31 & 602.12 & 26.36 & $<0.0001$ \\
\hline Diet Beverages & 3 & 0.71 & 8 & 0.84 & -5.19 & 1.00 & 0.0001 \\
\hline $\begin{array}{c}\text { Flavored or Enhanced } \\
\text { Water }\end{array}$ & 1 & 0.42 & 3 & 0.59 & -2.59 & 0.67 & 0.0018 \\
\hline Ready-to-Eat Cereals & 243 & 33.76 & 155 & 10.71 & 88.12 & 34.02 & 0.0205 \\
\hline Candy & 93 & 14.98 & 140 & 13.10 & -47.57 & 19.46 & 0.0273 \\
\hline
\end{tabular}




\begin{tabular}{|c|l|l|l|l|l|l|l|}
\hline Breads, Rolls, Tortillas & 562 & 35.94 & 459 & 15.31 & 102.63 & 43.14 & 0.0310 \\
\hline Coffee and Tea & 122 & 24.89 & 183 & 16.44 & -61.00 & 26.57 & 0.0364 \\
\hline Fruits & 274 & 27.28 & 214 & 12.18 & 59.45 & 26.36 & 0.0395 \\
\hline
\end{tabular}

Table 4: Significant Food Sources of Energy Intake (KJ) of Adults 19+ y of Age by OJ Consumption and by Survey Year.

${ }^{1}$ Intakes of foods was determined using all appropriate food codes from the What We Eat In America

${ }^{2} \mathrm{OJ}$ consumption in grams was determined using all orange juice codes from the What We Eat In America

${ }^{3}$ Linear regression coefficients were generated to determine differences between OJ consumers and OJ non-consumers

${ }^{4}$ Significance was defined as $\mathrm{p}<0.05$.

whole fruits $(123 \mathrm{KJ})$ and breads/rolls/tortillas (109 KJ) with a concomitant decrease in consumption of sweetened beverages $(-184 \mathrm{KJ})$ and mixed dishes-Mexican (-130 KJ). In 2015-2016, the increased energy intake among OJ consumers ( $959 \mathrm{KJ}$ ) as compared to non-consumers was mostly due to consumption of OJ (598 KJ), other $100 \%$ juice (602 KJ) and breads/rolls/tortillas (103 KJ) with a concomitant decrease in consumption of candy $(-48 \mathrm{KJ})$ and coffee/tea $(61 \mathrm{KJ})$.

Significant food sources for all nutrients that showed a significant association of changes in percentage of the population below the EAR/above the $\mathrm{AI}$ across deciles of $\mathrm{OJ}$ consumption are pre- sented by survey year in supplemental tables 2-13: The significant differences in food sources of iron, magnesium, riboflavin, thiamin, vitamins B6 and D, zinc and dietary fiber among 0J consumers and non-consumers were very small. The most notable differences were found in the food sources of calcium, folate, phosphorus, and sodium. In both survey years, OJ and other $100 \%$ juices were the major food sources of calcium, folate, and phosphorus among $0 \mathrm{~J}$ consumers compared to non-consumers. In 2015-2016, ready-toeat cereals were a major food source of folate among 0J consumers compared to non-consumers in both survey years, breads/rolls/ tortillas were the primary food source of sodium among OJ consumers compared to non-consumers.

\begin{tabular}{|c|c|c|c|c|c|c|c|}
\hline \multirow{3}{*}{ Significant food groups } & \multicolumn{7}{|c|}{ 2003-2004 Calcium (mg) of Adults 19+ Years of Age } \\
\hline & \multicolumn{2}{|c|}{ OJ consumers } & \multicolumn{2}{|c|}{ OJ non-consumers } & \multicolumn{3}{|c|}{ OJ consumers vs $0 \mathrm{~J}$ non-consumers } \\
\hline & Mean & SE & Mean & SE & Beta & SE & P value \\
\hline All Foods & 1028.80 & 31.68 & 845.91 & 18.62 & 182.90 & 32.17 & $<0.0001$ \\
\hline Orange Juice & 155.13 & 11.82 & 0.00 & 0.00 & 155.13 & 11.82 & $<0.0001$ \\
\hline $100 \%$ Juice & 158.21 & 11.88 & 2.69 & 0.45 & 155.51 & 11.83 & $<0.0001$ \\
\hline Coffee and Tea & 8.68 & 1.21 & 15.18 & 1.93 & -6.49 & 1.76 & 0.0022 \\
\hline Fruits & 10.51 & 0.91 & 7.15 & 0.36 & 3.36 & 0.96 & 0.0033 \\
\hline Mixed Dishes - Mexican & 12.93 & 2.47 & 30.97 & 6.21 & -18.04 & 6.14 & 0.0101 \\
\hline Breads, Rolls, Tortillas & 72.61 & 4.35 & 61.30 & 1.95 & 11.30 & 4.35 & 0.0202 \\
\hline $\begin{array}{l}\text { Mixed Dishes - Sandwiches } \\
\text { (single code) }\end{array}$ & 19.04 & 4.22 & 28.72 & 2.41 & -9.68 & 4.01 & 0.0290 \\
\hline \multicolumn{8}{|c|}{ 2015-2016 Calcium (mg) of Adults 19+ Years of Age } \\
\hline All Foods & 1137.08 & 28.73 & 926.80 & 21.30 & 210.28 & 35.08 & $<0.0001$ \\
\hline Orange Juice & 178.29 & 14.81 & 0.00 & 0.00 & 178.29 & 14.81 & $<0.0001$ \\
\hline 100\% Juice & 182.80 & 14.47 & 3.48 & 0.66 & 179.32 & 14.43 & $<0.0001$ \\
\hline
\end{tabular}




\begin{tabular}{|c|c|c|c|c|c|c|c|}
\hline Diet Beverages & 1.30 & 0.32 & 4.72 & 0.44 & -3.42 & 0.52 & $<0.0001$ \\
\hline Crackers & 1.80 & 0.45 & 3.67 & 0.32 & -1.88 & 0.55 & 0.0037 \\
\hline Candy & 3.59 & 0.78 & 5.84 & 0.61 & -2.25 & 0.90 & 0.0241 \\
\hline Alcoholic Beverages & 6.72 & 0.82 & 9.15 & 0.54 & -2.43 & 0.98 & 0.0251 \\
\hline Milk & 150.92 & 15.16 & 103.93 & 8.18 & 46.98 & 19.30 & 0.0279 \\
\hline Fruits & 13.83 & 2.25 & 9.42 & 0.68 & 4.41 & 1.84 & 0.0303 \\
\hline Ready-to-Eat Cereals & 22.39 & 4.08 & 12.34 & 0.89 & 10.05 & 4.23 & 0.0315 \\
\hline Cheese & 131.64 & 9.54 & 110.04 & 6.97 & 21.59 & 9.17 & 0.0326 \\
\hline
\end{tabular}

Supplemental Table 2: Significant Food Sources of Calcium (mg) of Adults 19+ Years of Age by Orange Juice (OJ) Consumption and by Survey Year.

\begin{tabular}{|c|c|c|c|c|c|c|c|}
\hline \multirow{3}{*}{ Significant food groups } & \multicolumn{7}{|c|}{ 2003-2004 Folate (DFE, mcg) of Adults 19+ Years of Age } \\
\hline & \multicolumn{2}{|c|}{ OJ consumers } & \multicolumn{2}{|c|}{ OJ non-consumers } & \multicolumn{3}{|c|}{ OJ consumers vs $0 \mathrm{~J}$ non-consumers } \\
\hline & Mean & SE & Mean & SE & Beta & SE & P value \\
\hline All Foods & 637.59 & 20.22 & 517.30 & 10.14 & 120.29 & 18.61 & $<0.0001$ \\
\hline Orange Juice & 73.04 & 4.00 & 0.00 & 0.00 & 73.04 & 4.00 & $<0.0001$ \\
\hline $100 \%$ Juice & 74.71 & 3.97 & 2.10 & 0.42 & 72.61 & 3.91 & $<0.0001$ \\
\hline Snack/Meal Bars & 1.48 & 0.52 & 6.02 & 0.81 & -4.54 & 0.94 & 0.0002 \\
\hline Fruits & 12.74 & 1.39 & 7.60 & 0.45 & 5.14 & 1.30 & 0.0013 \\
\hline Coffee and Tea & 10.39 & 0.91 & 14.23 & 0.81 & -3.84 & 1.38 & 0.0142 \\
\hline Condiments and Sauces & 4.70 & 0.78 & 2.73 & 0.27 & 1.97 & 0.75 & 0.0185 \\
\hline Breads, Rolls, Tortillas & 99.40 & 6.15 & 83.67 & 3.11 & 15.72 & 6.29 & 0.0244 \\
\hline Ready-to-Eat Cereals & 124.42 & 18.22 & 86.42 & 6.51 & 38.00 & 17.09 & 0.0420 \\
\hline \multicolumn{8}{|c|}{ 2015-2016 Folate (DFE, mcg) of Adults 19+ Years of Age } \\
\hline All Foods & 637.58 & 28.93 & 498.12 & 10.47 & 139.47 & 32.74 & 0.0007 \\
\hline Orange Juice & 58.41 & 2.16 & 0.00 & 0.00 & 58.41 & 2.16 & $<0.0001$ \\
\hline $100 \%$ Juice & 59.83 & 2.11 & 1.34 & 0.26 & 58.49 & 2.03 & $<0.0001$ \\
\hline $\begin{array}{c}\text { Protein and Nutritional } \\
\text { Powders }\end{array}$ & 1.78 & 1.06 & 9.37 & 2.15 & -7.59 & 2.71 & 0.0135 \\
\hline Fruits & 13.80 & 1.83 & 10.21 & 0.74 & 3.59 & 1.44 & 0.0249 \\
\hline Ready-to-Eat Cereals & 139.39 & 23.09 & 80.99 & 6.59 & 58.41 & 24.18 & 0.0289 \\
\hline Seafood & 2.35 & 0.57 & 3.27 & 0.50 & -0.91 & 0.39 & 0.0334 \\
\hline Cured Meats/Poultry & 0.59 & 0.12 & 1.12 & 0.19 & -0.53 & 0.23 & 0.0348 \\
\hline Sweet Bakery Products & 29.13 & 2.62 & 23.71 & 1.09 & 5.42 & 2.40 & 0.0391 \\
\hline
\end{tabular}

Supplemental Table 3: Significant Food Sources of Folate (DFE, mcg) of Adults 19+ Years of Age by Orange Juice (OJ) Consumption and by Survey Year. 


\begin{tabular}{|c|c|c|c|c|c|c|c|}
\hline \multirow{3}{*}{ Significant food groups } & \multicolumn{7}{|c|}{ 2003-2004 Iron (mg) of Adults 19+ Years of Age } \\
\hline & \multicolumn{2}{|c|}{ OJ consumers } & \multicolumn{2}{|c|}{ OJ non-consumers } & \multicolumn{3}{|c|}{ OJ consumers vs $0 \mathrm{~J}$ non-consumers } \\
\hline & Mean & SE & Mean & SE & Beta & SE & P value \\
\hline All Foods & 17.87 & 0.67 & 15.29 & 0.17 & 2.57 & 0.68 & 0.0019 \\
\hline Orange Juice & 1.14 & 0.06 & 0.00 & 0.00 & 1.14 & 0.06 & $<0.0001$ \\
\hline $100 \%$ Juice & 1.24 & 0.06 & 0.11 & 0.02 & 1.13 & 0.07 & $<0.0001$ \\
\hline Fruits & 0.28 & 0.02 & 0.16 & 0.01 & 0.12 & 0.02 & 0.0002 \\
\hline Sweetened Beverages & 0.40 & 0.03 & 0.54 & 0.02 & -0.14 & 0.03 & 0.0006 \\
\hline Coffee and Tea & 0.10 & 0.01 & 0.13 & 0.01 & -0.03 & 0.01 & 0.0050 \\
\hline Breads, Rolls, Tortillas & 2.19 & 0.13 & 1.79 & 0.06 & 0.40 & 0.14 & 0.0130 \\
\hline Ready-to-Eat Cereals & 3.22 & 0.55 & 1.99 & 0.13 & 1.23 & 0.56 & 0.0436 \\
\hline \multicolumn{8}{|c|}{ 2015-2016 Iron (mg) of Adults 19+ Years of Age } \\
\hline All Foods & 15.76 & 0.60 & 13.77 & 0.19 & 1.98 & 0.69 & 0.0112 \\
\hline Orange Juice & 0.39 & 0.01 & 0.00 & 0.00 & 0.39 & 0.01 & $<0.0001$ \\
\hline 100\% Juice & 0.45 & 0.03 & 0.05 & 0.01 & 0.40 & 0.03 & $<0.0001$ \\
\hline Diet Beverages & 0.03 & 0.01 & 0.08 & 0.01 & -0.05 & 0.01 & 0.0020 \\
\hline Coffee and Tea & 0.07 & 0.01 & 0.10 & 0.01 & -0.03 & 0.01 & 0.0036 \\
\hline $\begin{array}{c}\text { Protein and Nutritional } \\
\text { Powders }\end{array}$ & 0.04 & 0.03 & 0.22 & 0.05 & -0.18 & 0.06 & 0.0122 \\
\hline Ready-to-Eat Cereals & 3.11 & 0.43 & 1.83 & 0.13 & 1.28 & 0.46 & 0.0142 \\
\hline Milk & 0.03 & 0.00 & 0.02 & 0.00 & 0.01 & 0.00 & 0.0291 \\
\hline Cured Meats/Poultry & 0.18 & 0.02 & 0.24 & 0.02 & -0.06 & 0.03 & 0.0436 \\
\hline
\end{tabular}

Supplemental Table 4: Significant Food Sources of Iron (mg) of Adults 19+ Years of Age by Orange Juice (OJ) Consumption and by Survey Year.

\begin{tabular}{|c|c|c|c|c|c|c|c|}
\hline & \multicolumn{7}{|c|}{$\mathbf{2 0 0 3 - 2 0 0 4}$ Magnesium (mg) of Adults 19+ Years of Age } \\
\hline Significant food groups & \multicolumn{2}{|c|}{ OJ consumers } & \multicolumn{2}{|c|}{ OJ non-consumers } & \multicolumn{2}{c|}{ OJ consumers vs OJ non-consumers } \\
\hline & Mean & SE & Mean & SE & Beta & SE & P value \\
\hline All Foods & 322.15 & 8.11 & 271.67 & 4.45 & 50.48 & 7.23 & $<0.0001$ \\
\hline Orange Juice & 33.83 & 1.28 & 0.00 & 0.00 & 33.83 & 1.28 & $<0.0001$ \\
\hline 100\% Juice & & & & & & & \\
\hline Fruits & 36.66 & 1.65 & 2.29 & 0.38 & 34.37 & 1.61 & $<0.0001$ \\
\hline Coffee and Tea & 14.90 & 1.34 & 8.15 & 0.52 & 6.75 & 1.34 & 0.0001 \\
\hline Mixed Dishes - Mexican & 14.14 & 0.70 & 20.66 & 1.25 & -6.52 & 1.35 & 0.0002 \\
\hline Plant-based Protein Foods & 3.09 & 0.46 & 7.33 & 1.51 & -4.23 & 1.38 & 0.0077 \\
\hline Breads, Rolls, Tortillas & 28.03 & 3.15 & 19.66 & 1.25 & 8.36 & 3.35 & 0.0247 \\
\hline Ready-to-Eat Cereals & 12.56 & 1.85 & 8.49 & 0.77 & 4.07 & 1.72 & 0.0321 \\
\hline Meats & 6.36 & 0.68 & 7.70 & 0.48 & -1.34 & 0.61 & 0.0446 \\
\hline
\end{tabular}




\begin{tabular}{|c|c|c|c|c|c|c|c|}
\hline \multicolumn{8}{|c|}{ 2015-2016 Magnesium (mg) of Adults 19+ Years of Age } \\
\hline All Foods & 343.21 & 10.68 & 301.21 & 5.51 & 42.00 & 11.01 & 0.0017 \\
\hline Orange Juice & 32.94 & 1.31 & 0.00 & 0.00 & 32.94 & 1.31 & $<0.0001$ \\
\hline $100 \%$ Juice & 34.97 & 1.29 & 1.74 & 0.22 & 33.23 & 1.28 & $<0.0001$ \\
\hline Diet Beverages & 0.34 & 0.09 & 1.06 & 0.10 & -0.72 & 0.13 & 0.0001 \\
\hline Coffee and Tea & 12.75 & 1.24 & 20.48 & 1.50 & -7.73 & 2.16 & 0.0028 \\
\hline Fruits & 14.16 & 1.55 & 10.45 & 0.73 & 3.71 & 1.41 & 0.0192 \\
\hline Breads, Rolls, Tortillas & 21.91 & 2.28 & 16.16 & 0.52 & 5.75 & 2.23 & 0.0211 \\
\hline Milk & 13.63 & 1.37 & 9.36 & 0.74 & 4.27 & 1.72 & 0.0250 \\
\hline
\end{tabular}

Supplemental Table 5: Significant Food Sources of Magnesium (mg) of Adults 19+ Years of Age by Orange Juice (OJ) Consumption and by Survey Year.

\begin{tabular}{|c|c|c|c|c|c|c|c|}
\hline \multirow{3}{*}{ Significant food groups } & \multicolumn{7}{|c|}{ 2003-2004 Phosphorus (mg) of Adults 19+ Years of Age } \\
\hline & \multicolumn{2}{|c|}{ OJ consumers } & \multicolumn{2}{|c|}{ OJ non-consumers } & \multicolumn{3}{|c|}{ OJ consumers vs $0 \mathrm{~J}$ non-consumers } \\
\hline & Mean & SE & Mean & SE & Beta & SE & P value \\
\hline All Foods & 1402.38 & 34.82 & 1317.16 & 18.95 & 85.22 & 36.01 & 0.0318 \\
\hline Orange Juice & 45.16 & 1.73 & 0.00 & 0.00 & 45.16 & 1.73 & $<0.0001$ \\
\hline $100 \%$ Juice & 49.51 & 1.95 & 3.35 & 0.56 & 46.17 & 1.86 & $<0.0001$ \\
\hline Fruits & 19.24 & 1.69 & 10.49 & 0.61 & 8.75 & 1.70 & 0.0001 \\
\hline Coffee and Tea & 10.75 & 1.10 & 18.41 & 1.98 & -7.66 & 1.90 & 0.0011 \\
\hline Diet Beverages & 7.01 & 1.05 & 12.07 & 1.32 & -5.07 & 1.57 & 0.0056 \\
\hline Mixed Dishes - Mexican & 19.05 & 3.54 & 41.19 & 8.27 & -22.14 & 8.85 & 0.0245 \\
\hline Ready-to-Eat Cereals & 39.77 & 6.33 & 26.08 & 2.19 & 13.68 & 5.73 & 0.0305 \\
\hline $\begin{array}{l}\text { Mixed Dishes - Sandwiches } \\
\text { (single code) }\end{array}$ & 28.44 & 6.10 & 41.51 & 3.85 & -13.07 & 5.79 & 0.0394 \\
\hline Breads, Rolls, Tortillas & 76.48 & 5.34 & 65.86 & 3.76 & 10.63 & 4.81 & 0.0431 \\
\hline \multicolumn{8}{|c|}{ 2015-2016 Phosphorus (mg) of Adults 19+ Years of Age } \\
\hline All Foods & 1506.78 & 39.37 & 1369.65 & 23.15 & 137.13 & 43.09 & 0.0062 \\
\hline Orange Juice & 85.65 & 4.40 & 0.00 & 0.00 & 85.65 & 4.40 & $<0.0001$ \\
\hline $100 \%$ Juice & 88.61 & 4.11 & 2.48 & 0.34 & 86.13 & 4.11 & $<0.0001$ \\
\hline Diet Beverages & 3.15 & 0.82 & 7.82 & 0.95 & -4.68 & 1.07 & 0.0006 \\
\hline Milk & 116.84 & 11.74 & 79.76 & 6.30 & 37.08 & 14.71 & 0.0235 \\
\hline Crackers & 6.39 & 1.71 & 10.70 & 0.71 & -4.31 & 1.74 & 0.0257 \\
\hline Ready-to-Eat Cereals & 41.00 & 5.46 & 27.14 & 2.10 & 13.86 & 5.89 & 0.0326 \\
\hline Fruits & 17.81 & 1.99 & 13.73 & 0.87 & 4.08 & 1.84 & 0.0420 \\
\hline Breads, Rolls, Tortillas & 75.12 & 7.54 & 59.77 & 2.44 & 15.35 & 6.97 & 0.0438 \\
\hline
\end{tabular}

Supplemental Table 6: Significant Food Sources of Phosphorus (mg) of Adults 19+ Years of Age by Orange Juice (OJ) Consumption and by Survey Year. 


\begin{tabular}{|c|c|c|c|c|c|c|c|}
\hline \multirow{3}{*}{ Significant food groups } & \multicolumn{7}{|c|}{ 2003-2004 Riboflavin (mg) of Adults 19+ Years of Age } \\
\hline & \multicolumn{2}{|c|}{ OJ consumers } & \multicolumn{2}{|c|}{ OJ non-consumers } & \multicolumn{3}{|c|}{ OJ consumers vs $0 \mathrm{~J}$ non-consumers } \\
\hline & Mean & SE & Mean & SE & Beta & SE & P value \\
\hline All Foods & 2.37 & 0.06 & 2.23 & 0.04 & 0.14 & 0.04 & 0.0058 \\
\hline Orange Juice & 0.08 & 0.00 & 0.00 & 0.00 & 0.08 & 0.00 & $<0.0001$ \\
\hline Fruits & 0.05 & 0.00 & 0.03 & 0.00 & 0.02 & 0.00 & $<0.0001$ \\
\hline $100 \%$ Juice & 0.09 & 0.00 & 0.01 & 0.00 & 0.08 & 0.00 & $<0.0001$ \\
\hline Coffee and Tea & 0.17 & 0.01 & 0.26 & 0.02 & -0.09 & 0.02 & 0.0016 \\
\hline Diet Beverages & 0.02 & 0.00 & 0.03 & 0.00 & -0.01 & 0.00 & 0.0058 \\
\hline Breads, Rolls, Tortillas & 0.19 & 0.01 & 0.16 & 0.01 & 0.03 & 0.01 & 0.0105 \\
\hline \multicolumn{8}{|c|}{ 2015-2016 Riboflavin (mg) of Adults 19+ Years of Age } \\
\hline All Foods & 2.25 & 0.08 & 2.16 & 0.04 & 0.10 & 0.08 & 0.2379 \\
\hline Orange Juice & 0.12 & 0.00 & 0.00 & 0.00 & 0.12 & 0.00 & $<0.0001$ \\
\hline $100 \%$ Juice & 0.12 & 0.01 & 0.00 & 0.00 & 0.12 & 0.00 & $<0.0001$ \\
\hline Diet Beverages & 0.01 & 0.00 & 0.05 & 0.01 & -0.04 & 0.01 & 0.0012 \\
\hline Coffee and Tea & 0.18 & 0.02 & 0.26 & 0.01 & -0.08 & 0.02 & 0.0029 \\
\hline Mixed Dishes - Mexican & 0.05 & 0.01 & 0.07 & 0.01 & -0.02 & 0.01 & 0.0101 \\
\hline Sweetened Beverages & 0.04 & 0.01 & 0.08 & 0.01 & -0.04 & 0.01 & 0.0130 \\
\hline Candy & 0.01 & 0.00 & 0.01 & 0.00 & 0.00 & 0.00 & 0.0154 \\
\hline Milk & 0.23 & 0.02 & 0.16 & 0.01 & 0.07 & 0.03 & 0.0332 \\
\hline Fruits & 0.04 & 0.00 & 0.03 & 0.00 & 0.01 & 0.00 & 0.0403 \\
\hline
\end{tabular}

Supplemental Table 7: Significant Food Sources of Riboflavin (mg) of Adults 19+ Years of Age by Orange Juice (OJ) Consumption and by Survey Year.

\begin{tabular}{|c|c|c|c|c|c|c|c|}
\hline \multirow{3}{*}{ Significant food groups } & \multicolumn{7}{|c|}{ 2003-2004 Thiamin (mg) of Adults 19+ Years of Age } \\
\hline & \multicolumn{2}{|c|}{ OJ consumers } & \multicolumn{2}{|c|}{ OJ non-consumers } & \multicolumn{3}{|c|}{ OJ consumers vs $0 \mathrm{~J}$ non-consumers } \\
\hline & Mean & SE & Mean & SE & Beta & SE & P value \\
\hline All Foods & 1.89 & 0.04 & 1.61 & 0.02 & 0.28 & 0.04 & $<0.0001$ \\
\hline Orange Juice & 0.20 & 0.01 & 0.00 & 0.00 & 0.20 & 0.01 & $<0.0001$ \\
\hline $100 \%$ Juice & 0.21 & 0.01 & 0.01 & 0.00 & 0.20 & 0.01 & $<0.0001$ \\
\hline Fruits & 0.04 & 0.00 & 0.02 & 0.00 & 0.02 & 0.00 & 0.0002 \\
\hline Coffee and Tea & 0.03 & 0.00 & 0.04 & 0.00 & -0.01 & 0.00 & 0.0022 \\
\hline Diet Beverages & 0.00 & 0.00 & 0.01 & 0.00 & 0.00 & 0.00 & 0.0057 \\
\hline Meats & 0.05 & 0.01 & 0.08 & 0.01 & -0.03 & 0.01 & 0.0060 \\
\hline Breads, Rolls, Tortillas & 0.28 & 0.02 & 0.23 & 0.01 & 0.05 & 0.02 & 0.0103 \\
\hline \multicolumn{8}{|c|}{ 2015-2016 Thiamin (mg) of Adults 19+ Years of Age } \\
\hline
\end{tabular}




\begin{tabular}{|c|c|c|c|c|c|c|c|}
\hline All Foods & 1.84 & 0.06 & 1.55 & 0.02 & 0.28 & 0.07 & 0.0010 \\
\hline Orange Juice & 0.15 & 0.01 & 0.00 & 0.00 & 0.15 & 0.01 & $<0.0001$ \\
\hline $100 \%$ Juice & & & & & & & \\
\hline Diet Beverages & 0.15 & 0.01 & 0.01 & 0.00 & 0.15 & 0.01 & $<0.0001$ \\
\hline Coffee and Tea & 0.03 & 0.00 & 0.04 & 0.00 & -0.01 & 0.00 & 0.0033 \\
\hline Sweet Bakery Products & 0.08 & 0.01 & 0.06 & 0.00 & 0.02 & 0.01 & 0.0329 \\
\hline Alcoholic Beverages & 0.01 & 0.00 & 0.01 & 0.00 & 0.00 & 0.00 & 0.0345 \\
\hline Fruits & 0.04 & 0.01 & 0.03 & 0.00 & 0.01 & 0.00 & 0.0355 \\
\hline Ready-to-Eat Cereals & 0.18 & 0.03 & 0.12 & 0.01 & 0.06 & 0.03 & 0.0394 \\
\hline
\end{tabular}

Supplemental Table 8: Significant Food Sources of Thiamin (mg) of Adults 19+ Years of Age by Orange Juice (OJ) Consumption and by Survey Year.

\begin{tabular}{|c|c|c|c|c|c|c|c|}
\hline \multirow{3}{*}{ Significant food groups } & \multicolumn{7}{|c|}{ 2003-2004 Vitamin B6 (mg) of Adults 19+ Years of Age } \\
\hline & \multicolumn{2}{|c|}{ OJ consumers } & \multicolumn{2}{|c|}{ OJ non-consumers } & \multicolumn{3}{|c|}{ OJ consumers vs $0 \mathrm{~J}$ non-consumers } \\
\hline & Mean & SE & Mean & SE & Beta & SE & P value \\
\hline All Foods & 2.18 & 0.06 & 1.80 & 0.03 & 0.38 & 0.05 & $<0.0001$ \\
\hline Orange Juice & 0.24 & 0.01 & 0.00 & 0.00 & 0.24 & 0.01 & $<0.0001$ \\
\hline Fruits & 0.15 & 0.01 & 0.08 & 0.01 & 0.07 & 0.01 & $<0.0001$ \\
\hline $100 \%$ Juice & 0.27 & 0.01 & 0.02 & 0.00 & 0.25 & 0.01 & $<0.0001$ \\
\hline Coffee and Tea & 0.00 & 0.00 & 0.01 & 0.00 & 0.00 & 0.00 & 0.0005 \\
\hline Mixed Dishes - Mexican & 0.02 & 0.00 & 0.05 & 0.01 & -0.02 & 0.01 & 0.0338 \\
\hline Ready-to-Eat Cereals & 0.31 & 0.04 & 0.21 & 0.01 & 0.09 & 0.04 & 0.0360 \\
\hline $\begin{array}{l}\text { Mixed Dishes - Sandwiches } \\
\text { (single code) }\end{array}$ & 0.04 & 0.01 & 0.05 & 0.00 & -0.02 & 0.01 & 0.0404 \\
\hline \multicolumn{8}{|c|}{ 2015-2016 Vitamin B6 (mg) of Adults 19+ Years of Age } \\
\hline All Foods & 2.40 & 0.09 & 2.11 & 0.05 & 0.29 & 0.09 & 0.0059 \\
\hline Orange Juice & 0.22 & 0.01 & 0.00 & 0.00 & 0.22 & 0.01 & $<0.0001$ \\
\hline 100\% Juice & 0.23 & 0.01 & 0.01 & 0.00 & 0.22 & 0.01 & $<0.0001$ \\
\hline Diet Beverages & 0.00 & 0.00 & 0.06 & 0.02 & -0.06 & 0.02 & 0.0070 \\
\hline Plant-based Protein Foods & 0.04 & 0.00 & 0.06 & 0.01 & -0.02 & 0.01 & 0.0145 \\
\hline Flavored or Enhanced Water & 0.00 & 0.00 & 0.01 & 0.00 & -0.01 & 0.00 & 0.0202 \\
\hline Other & 0.00 & 0.00 & 0.00 & 0.00 & 0.00 & 0.00 & 0.0276 \\
\hline Milk & 0.05 & 0.00 & 0.03 & 0.00 & 0.01 & 0.01 & 0.0281 \\
\hline Candy & 0.00 & 0.00 & 0.00 & 0.00 & 0.00 & 0.00 & 0.0301 \\
\hline Fruits & 0.13 & 0.01 & 0.10 & 0.01 & 0.03 & 0.01 & 0.0341 \\
\hline
\end{tabular}

Supplemental Table 9: Significant Food Sources of Vitamin B6 (mg) of Adults 19+ Years of Age by Orange Juice (OJ) Consumption and by Survey Year. 


\begin{tabular}{|c|c|c|c|c|c|c|c|}
\hline \multirow{3}{*}{ Significant food groups } & \multicolumn{7}{|c|}{ 2003-2004 Vitamin D (D2 + D3) $(\mu \mathrm{g})$ of Adults 19+ Years of Age } \\
\hline & \multicolumn{2}{|c|}{ OJ consumers } & \multicolumn{2}{|c|}{ OJ non-consumers } & \multicolumn{3}{|c|}{ OJ consumers vs $0 \mathrm{~J}$ non-consumers } \\
\hline & Mean & SE & Mean & SE & Beta & SE & P value \\
\hline All Foods & 4.82 & 0.33 & 4.42 & 0.17 & 0.40 & 0.33 & 0.2467 \\
\hline Orange Juice & 0.00 & 0.00 & 0.00 & 0.00 & . & . & . \\
\hline Mixed Dishes - Mexican & 0.01 & 0.00 & 0.03 & 0.01 & -0.02 & 0.01 & 0.0085 \\
\hline Coffee and Tea & 0.02 & 0.01 & 0.07 & 0.02 & -0.05 & 0.02 & 0.0136 \\
\hline White Potatoes & 0.02 & 0.00 & 0.04 & 0.00 & -0.01 & 0.00 & 0.0157 \\
\hline Cooked Grains & 0.00 & 0.00 & 0.00 & 0.00 & 0.00 & 0.00 & 0.0182 \\
\hline Sweetened Beverages & 0.03 & 0.01 & 0.05 & 0.01 & -0.02 & 0.01 & 0.0266 \\
\hline Poultry & 0.04 & 0.01 & 0.05 & 0.00 & -0.01 & 0.01 & 0.0413 \\
\hline \multicolumn{8}{|c|}{ 2015-2016 Vitamin D (D2 + D3) $(\mu \mathrm{g})$ of Adults 19+ Years of Age } \\
\hline All Foods & 5.49 & 0.23 & 4.54 & 0.16 & 0.95 & 0.30 & 0.0060 \\
\hline Orange Juice & 0.70 & 0.07 & 0.00 & 0.00 & 0.70 & 0.07 & $<0.0001$ \\
\hline $100 \%$ Juice & 0.70 & 0.07 & 0.00 & 0.00 & 0.70 & 0.07 & $<0.0001$ \\
\hline Alcoholic Beverages & 0.00 & 0.00 & 0.01 & 0.00 & -0.01 & 0.00 & 0.0054 \\
\hline $\begin{array}{l}\text { Mixed Dishes - Sandwiches } \\
\text { (single code) }\end{array}$ & 0.12 & 0.02 & 0.17 & 0.01 & -0.05 & 0.02 & 0.0134 \\
\hline $\begin{array}{c}\text { Protein and Nutritional } \\
\text { Powders }\end{array}$ & 0.02 & 0.01 & 0.11 & 0.03 & -0.09 & 0.04 & 0.0191 \\
\hline Milk & 1.54 & 0.16 & 1.07 & 0.08 & 0.47 & 0.21 & 0.0371 \\
\hline
\end{tabular}

Supplemental Table 10: Significant Food Sources of Vitamin D (D2 + D3) ( $\mu \mathrm{g})$ of Adults 19+ Years of Age by Orange Juice (OJ) Consumption and by Survey Year.

\begin{tabular}{|c|c|c|c|c|c|c|c|}
\hline \multirow{3}{*}{ Significant food groups } & \multicolumn{7}{|c|}{ 2003-2004 Zinc (mg) of Adults 19+ Years of Age } \\
\hline & \multicolumn{2}{|c|}{ OJ consumers } & \multicolumn{2}{|c|}{ OJ non-consumers } & \multicolumn{3}{|c|}{ OJ consumers vs $0 \mathrm{~J}$ non-consumers } \\
\hline & Mean & SE & Mean & SE & Beta & SE & P value \\
\hline All Foods & 12.63 & 0.48 & 11.94 & 0.19 & 0.69 & 0.43 & 0.1278 \\
\hline Orange Juice & 0.20 & 0.01 & 0.00 & 0.00 & 0.20 & 0.01 & $<0.0001$ \\
\hline $100 \%$ Juice & 0.23 & 0.01 & 0.02 & 0.00 & 0.21 & 0.01 & $<0.0001$ \\
\hline Fruits & 0.12 & 0.01 & 0.07 & 0.00 & 0.06 & 0.01 & 0.0004 \\
\hline Coffee and Tea & 0.09 & 0.01 & 0.13 & 0.01 & -0.05 & 0.01 & 0.0008 \\
\hline Diet Beverages & 0.01 & 0.00 & 0.01 & 0.00 & -0.01 & 0.00 & 0.0035 \\
\hline Snack/Meal Bars & 0.03 & 0.01 & 0.07 & 0.01 & -0.04 & 0.01 & 0.0045 \\
\hline Breads, Rolls, Tortillas & 0.59 & 0.04 & 0.49 & 0.02 & 0.10 & 0.04 & 0.0150 \\
\hline Ready-to-Eat Cereals & 1.29 & 0.22 & 0.82 & 0.06 & 0.46 & 0.21 & 0.0425 \\
\hline \multicolumn{8}{|c|}{ 2015-2016 Zinc (mg) of Adults 19+ Years of Age } \\
\hline All Foods & 11.54 & 0.42 & 11.17 & 0.20 & 0.38 & 0.47 & 0.4363 \\
\hline
\end{tabular}




\begin{tabular}{|c|c|c|c|c|c|c|c|}
\hline Orange Juice & 0.21 & 0.01 & 0.00 & 0.00 & 0.21 & 0.01 & $<0.0001$ \\
\hline & & & & & & & \\
\hline 100\% Juice & 0.24 & 0.02 & 0.02 & 0.00 & 0.22 & 0.02 & $<0.0001$ \\
\hline Diet Beverages & 0.00 & 0.00 & 0.01 & 0.00 & 0.00 & 0.00 & 0.0013 \\
\hline Mixed Dishes - Mexican & 0.44 & 0.10 & 0.65 & 0.09 & -0.21 & 0.06 & 0.0032 \\
\hline Breads, Rolls, Tortillas & 0.55 & 0.05 & 0.42 & 0.01 & 0.13 & 0.05 & 0.0183 \\
\hline Plain Water & 0.07 & 0.01 & 0.08 & 0.00 & -0.02 & 0.01 & 0.0299 \\
\hline Milk & 0.54 & 0.05 & 0.37 & 0.03 & 0.16 & 0.07 & 0.0304 \\
\hline Coffee and Tea & 0.10 & 0.02 & 0.15 & 0.01 & -0.04 & 0.02 & 0.0422 \\
\hline
\end{tabular}

Supplemental Table 11: Significant Food Sources of Zinc (mg) of Adults 19+ Years of Age by Orange Juice (OJ) Consumption and by Survey Year.

\begin{tabular}{|c|c|c|c|c|c|c|c|}
\hline \multirow{3}{*}{ Significant food groups } & \multicolumn{7}{|c|}{ 2003-2004 Dietary Fiber (g) of Adults 19+ Years of Age } \\
\hline & \multicolumn{2}{|c|}{ OJ consumers } & \multicolumn{2}{|c|}{ OJ non-consumers } & \multicolumn{3}{|c|}{ OJ consumers vs $0 \mathrm{~J}$ non-consumers } \\
\hline & Mean & SE & Mean & SE & Beta & SE & P value \\
\hline All Foods & 17.66 & 0.63 & 15.07 & 0.34 & 2.59 & 0.48 & 0.0001 \\
\hline Orange Juice & 0.64 & 0.02 & 0.00 & 0.00 & 0.64 & 0.02 & $<0.0001$ \\
\hline $100 \%$ Juice & 0.71 & 0.03 & 0.05 & 0.01 & 0.66 & 0.03 & $<0.0001$ \\
\hline Fruits & 2.20 & 0.18 & 1.30 & 0.07 & 0.91 & 0.16 & 0.0001 \\
\hline Coffee and Tea & 0.01 & 0.00 & 0.03 & 0.01 & -0.02 & 0.01 & 0.0090 \\
\hline Breads, Rolls, Tortillas & 2.18 & 0.14 & 1.78 & 0.09 & 0.40 & 0.14 & 0.0095 \\
\hline Mixed Dishes - Mexican & 0.24 & 0.03 & 0.62 & 0.16 & -0.38 & 0.14 & 0.0152 \\
\hline Ready-to-Eat Cereals & 1.10 & 0.17 & 0.71 & 0.06 & 0.39 & 0.16 & 0.0255 \\
\hline \multicolumn{8}{|c|}{ 2015-2016 Dietary Fiber (g) of Adults 19+ Years of Age } \\
\hline All Foods & 19.48 & 0.80 & 16.92 & 0.40 & 2.56 & 0.82 & 0.0068 \\
\hline Orange Juice & 0.89 & 0.04 & 0.00 & 0.00 & 0.89 & 0.04 & $<0.0001$ \\
\hline $100 \%$ Juice & 0.94 & 0.04 & 0.06 & 0.01 & 0.88 & 0.04 & $<0.0001$ \\
\hline Eggs & 0.01 & 0.00 & 0.02 & 0.00 & -0.02 & 0.00 & 0.0002 \\
\hline Cheese & 0.00 & 0.00 & 0.02 & 0.00 & -0.01 & 0.00 & 0.0039 \\
\hline Alcoholic Beverages & 0.00 & 0.00 & 0.01 & 0.00 & -0.01 & 0.00 & 0.0042 \\
\hline Yogurt & 0.02 & 0.01 & 0.05 & 0.01 & -0.03 & 0.01 & 0.0099 \\
\hline Breads, Rolls, Tortillas & 1.99 & 0.18 & 1.56 & 0.05 & 0.43 & 0.18 & 0.0303 \\
\hline
\end{tabular}

Supplemental Table 12: Significant Food Sources of Dietary Fiber (g) of Adults 19+ Years of Age by Orange Juice Consumption and by Survey Year. 


\begin{tabular}{|c|c|c|c|c|c|c|c|}
\hline \multirow{3}{*}{ Significant food groups } & \multicolumn{7}{|c|}{ 2003-2004 Sodium (mg) of Adults 19+ Years of Age } \\
\hline & \multicolumn{2}{|c|}{ OJ consumers } & \multicolumn{2}{|c|}{ OJ non-consumers } & \multicolumn{3}{|c|}{ OJ consumers vs $\mathrm{OJ}$ non-consumers } \\
\hline & Mean & SE & Mean & SE & Beta & SE & $P$ value \\
\hline All Foods & 3725.38 & 84.92 & 3604.40 & 38.70 & 120.98 & 95.69 & 0.2254 \\
\hline Orange Juice & 6.09 & 0.23 & 0.00 & 0.00 & 6.09 & 0.23 & $<0.0001$ \\
\hline Coffee and Tea & 11.02 & 0.86 & 16.43 & 1.25 & -5.41 & 1.53 & 0.0030 \\
\hline Alcoholic Beverages & 7.20 & 0.90 & 17.06 & 2.73 & -9.86 & 2.82 & 0.0033 \\
\hline Breads, Rolls, Tortillas & 343.58 & 20.01 & 280.61 & 8.91 & 62.97 & 19.59 & 0.0058 \\
\hline $100 \%$ Juice & 15.49 & 3.48 & 6.08 & 1.67 & 9.41 & 3.72 & 0.0231 \\
\hline Fruits & 2.52 & 0.35 & 1.65 & 0.15 & 0.87 & 0.37 & 0.0314 \\
\hline Ready-to-Eat Cereals & 79.29 & 11.00 & 56.24 & 3.50 & 23.05 & 10.28 & 0.0405 \\
\hline \multicolumn{8}{|c|}{ 2015-2016 Sodium (mg) of Adults 19+ Years of Age } \\
\hline All Foods & 3662.01 & 88.87 & 3523.51 & 47.83 & 138.50 & 112.96 & 0.2390 \\
\hline Orange Juice & 6.35 & 0.35 & 0.00 & 0.00 & 6.35 & 0.35 & $<0.0001$ \\
\hline Diet Beverages & 2.72 & 0.68 & 11.98 & 1.36 & -9.26 & 1.35 & $<0.0001$ \\
\hline Breads, Rolls, Tortillas & 234.03 & 14.46 & 187.04 & 7.30 & 46.99 & 17.06 & 0.0148 \\
\hline Plain Water & 36.07 & 2.52 & 43.41 & 1.89 & -7.33 & 2.70 & 0.0160 \\
\hline Ready-to-Eat Cereals & 63.96 & 9.30 & 39.47 & 2.47 & 24.49 & 9.98 & 0.0268 \\
\hline Coffee and Tea & 14.65 & 1.86 & 19.79 & 1.02 & -5.14 & 2.12 & 0.0286 \\
\hline Milk & 56.67 & 5.52 & 39.50 & 3.07 & 17.17 & 7.14 & 0.0295 \\
\hline Sweetened Beverages & 30.87 & 4.30 & 40.87 & 2.62 & -10.01 & 4.51 & 0.0426 \\
\hline Candy & 5.72 & 1.34 & 9.52 & 0.98 & -3.79 & 1.71 & 0.0428 \\
\hline $\begin{array}{c}\text { Protein and Nutritional } \\
\text { Powders }\end{array}$ & 3.23 & 1.77 & 11.48 & 2.77 & -8.25 & 3.74 & 0.0435 \\
\hline Plant-based Protein Foods & 46.15 & 9.15 & 70.10 & 6.08 & -23.95 & 11.10 & 0.0476 \\
\hline
\end{tabular}

Supplemental Table 13: Significant Food Sources of Sodium (mg) of Adults 19+ Years of Age by Orange Juice (OJ) Consumption and by Survey Year.

\section{Discussion}

Approximately $13 \%$ of adults reported consuming $0 \mathrm{~J}$ with a mean intake of $39.5 \mathrm{~g} / \mathrm{d}(1.3 \mathrm{fl} \mathrm{oz})$ which was equivalent to 76 $\mathrm{KJ}$ (18.2 kcal) or $0.89 \%$ of total energy intake. On average adults consumed 0.92 cup eq of total fruits (2015-2016); 65\% were from whole fruit and $27 \%$ from $\mathrm{FJ}$ ( $50 \%$ was from 0 J). The recommended amount of fruits in the Healthy US-Style Eating Pattern at the 2,000-calorie level is 2 cup eq/d. given that FJ can be part of healthy eating patterns, at least half of the recommended amount of fruits should come from whole fruits because it is higher in fiber than FJ
[7] Based on the newly release recommendation the mean amount of total fruits consumed is far below the recommended amount and the proportion of whole fruit compared to FJ consumed is well within the recommended distribution.

The intake of fruits have significantly changed in the diets of adults from 2003-2016. Despite no significant change in consumption of fruits, the consumption of whole fruits increased with a concomitant decrease in consumption of FJ, specifically both $0 \mathrm{~J}$ and other $100 \%$ juices. This is consistent with the latest vital signs report by the Centers for Disease Control and Prevention [51,53]. 
Nutrient intake in adults has also changed from 2003-2016. Total energy intake decreased along with a decrease in intake of carbohydrates, specifically total sugars and added sugars. Total fiber intake increased with no significant trends in intakes of total protein, total fat, and saturated fat. Intakes of niacin and vitamin B6 increased while intakes of riboflavin, thiamin, and vitamin $\mathrm{C}$ decreased. Intakes of calcium, magnesium, and phosphorus increased while intakes of iron, sodium, and zinc decreased. Given that adults are currently under-consuming several nutrients (i.e. vitamins $A, D, E$, and C, folate, calcium, magnesium, fiber, and potassium), the percent of adults below the EAR or percent above the AI did not change from 2003-2016. The only positive trends were a significant increase in fiber and zinc intakes.

Given that a major focus of this study was on trends in OJ consumption and nutrient adequacy from 2003-2016, the most notable trends were found in the percent below the EAR or above the $\mathrm{AI}$ in 12 nutrients across the deciles of $\mathrm{OJ}$ consumption, the percent of adults with inadequate intake of folate, riboflavin, thiamin, vitamins B6 and D, calcium, iron, magnesium, phosphorus, and zinc decreased. The largest drop in the percent of adults with inadequate intake was between decile 1 ( $0 \mathrm{~g}$ of $0 \mathrm{~J}$ consumed) and decile 2 (100-145 g of OJ consumed). The percent of adults above the AI increased for dietary fiber and sodium. Studies have confirmed that $\mathrm{OJ}$ consumption increased nutrient adequacy in adults [8-13], specifically that of vitamin C, folate, potassium, and magnesium; all of which are key nutrients in 0J. The trends in nutrient adequacy across the deciles of $\mathrm{OJ}$ consumption was shown in nutrients for which $\mathrm{OJ}$ is not a significant source; thus, it was important to look at significant food sources of all 12 nutrients (including total energy intake) for $\mathrm{OJ}$ consumers compared to non-consumers.

Many studies have looked at differences in nutrient intakes of OJ consumers compared to non-consumers with the implication that any differences were solely from the contribution of $\mathrm{OJ}$ consumption $[11,12,14,20,28,30,31,34]$. Although this was recognized as a limitation, no further analyses were conducted to identify differences in other food sources of nutrients coming from the total diet. Results from this study clearly demonstrate differences in food patterns among OJ consumers and non-consumers which partially explains the differences in nutrient adequacy among the two groups that were part of this study. It is also interesting that the food sources of nutrients among OJ consumers versus nonconsumers has also varied over time.
In an effort to better understand the trends in nutrient adequacy by $0 \mathrm{~J}$ consumption, food sources of the significantly different nutrients were explored for survey year 2003-2004 compared to the survey year 2015-2016. The increased intake of energy in 2003-2004 among OJ consumers as compared to non-consumers was mostly due to consumption of OJ, other $100 \%$ juices, fruits, and breads/rolls/tortillas with a concomitant decrease in consumption of sweetened beverages, meats, and mixed dishes-Mexican. In 2015-2016 the increase in energy consumption among OJ consumers compared to non-consumers was mostly due to consumption of 0 J, $100 \%$ juices, ready-to-eat cereals, bread/rolls/tortillas and fruits with a concomitant decrease in consumption of flavored or enhanced water, candy, and coffee/tea.

The significant food sources of iron, riboflavin, thiamin, vitamins B6 and D, zinc, and fiber among OJ consumers compared to non-consumers were very small for both survey years. The most notable differences were found in the food sources of calcium, folate, phosphorus, and magnesium. For both survey years, the increase in calcium, folate, phosphorus, and magnesium was mostly due to increased consumption of $\mathrm{OJ}$ and other $100 \%$ juices. The predominant food sources of sodium was from bread/rolls/tortillas for both survey years; higher intakes among OJ consumers.

Strengths of this study include that it encompassed a large nationally representative sample achieved through combining several sets of NHANES releases, use of 2-days of intake and the NCI method to assess UI of OJ and the percentage of the population below recommended levels over time and across levels of $\mathrm{OJ}$ consumption. Identifying food sources of energy and nutrients for 2003-2004 and 2015-2016 for OJ consumers and non-consumers provided greater insight into the dietary patterns of these groups and strengthened the identification of $\mathrm{OJ}$ as the likely sources of changes in intake while also identify major pattern shifts (e.g., lower sweetened beverage consumption in 0 J consumers).

Limitations of this study are that NHANES is a cross-sectional study; thus, cause and effect relationships cannot be determined. Intake was self-reported, and subjects relied on memory of what they ate and underreporting or over-reporting of intake could have occurred. The possibility that self-reported data may include other juice cocktails and drinks that are not in the definition of $100 \%$ juice is possible and it is also well documented that energy intakes are under-reported, particularly among over-weight individuals 
[54-57]. Finally, examining linear trends in nutrient intake and nutrient adequacy across $0 \mathrm{~J}$ deciles does not imply that OJ consumption was solely associated with nutrient adequacy of some nutrients. It can be seen that there were differences in other food sources of nutrients among OJ consumers.

In conclusion, there were changes in intake and nutrient adequacy from 2003-2004 to 2015-2016. There were also changes in nutrient adequacy of adults below EAR/above AI across levels of $\mathrm{OJ}$ consumption for several key nutrients. These results suggest that consumption of $\mathrm{OJ}$ and other $100 \%$ juices were major sources of calcium, folate, phosphorus, and magnesium. Finally, food patterns varied among OJ consumers and non-consumers. This finding suggests that studies looking at consumption versus non-consumption of foods need to look at food patterns within the context of the total diet.

\section{Acknowledgements}

This work is a publication of the United States Department of Agriculture (USDA/ARS) Children's Nutrition Research Center, Department of Pediatrics, Baylor College of Medicine, Houston, Texas. The contents of this publication do not necessarily reflect the views or policies of the USDA, nor does mention of trade names, commercial products, or organizations imply endorsement from the US government. This research project was supported by the Florida Department of Citrus, and USDA-Agricultural Research Service through specific cooperative agreement 58-3092-5-001.

\section{Authors' Contributions}

T.A.N, C.O'N. and V.L.F contributed to the concept development and the overall research plan; V.L.F. contributed to the methodological and statistical aspects of the work; TAN wrote the initial draft; CO'N. and V.L.F. critically reviewed and edited the manuscript; TAN has primary responsibility for the final content. R.S contributed to the technical logistics and editing of the manuscript. All authors read and approved the final manuscript.

\section{Conflict of Interest}

The authors declare no conflict of interest.

\section{Bibliography}

1. US Department of Agriculture. "United states orange juice domestic consumption by year". (2020).
2. U S Department of Agriculture. "Fooddata central, orange juice, raw”. Agriculture Research Services 2019. (2020).

3. Khan T A., et al. "A lack of consideration of a dose-response relationship can lead to erroneous conclusions regarding 100\% fruit juice and the risk of cardiometabolic disease". European Journal of Clinical Nutrition 73.12 (2019): 1556-1560.

4. Walker R W., et al. "Fructose content in popular beverages made with and without high-fructose corn syrup". Nutrition 30.7-8 (2014): 928-935.

5. Dietary Guidelines Advisory Committee. "Scientific report of the 2015 dietary guidelines advisory committee: Advisory report to the secretary of health and human services and the secretary of agriculture". U.S. Department of Agriculture, Agricultural Research Service 2015 (2020).

6. Bray G A., et al. "Consumption of high-fructose corn syrup in beverages may play a role in the epidemic of obesity". American Journal of Clinical Nutrition 79.4 (2004): 537-543.

7. Dietary Guidelines Advisory Committee. Scientific report of the 2020 dietary guidelines advisory committee: Advisory report to the secretary of agriculture and the secretary of health and human services. Washington, DC: Agricultural Research Services (2020).

8. Rampersaud G C. "A comparison of nutrient density scores for 100\% fruit juices". Journal of Food Science 72.4 (2007): S261266.

9. Byrd-Bredbenner C., et al. "Satisfying america's fruit gap: Summary of an expert roundtable on the role of $100 \%$ fruit juice". Journal of Food Science 82.7 (2017): 1523-1534.

10. Crowe-White, K., et al. "Impact of $100 \%$ fruit juice consumption on diet and weight status of children: An evidence-based review". Critical Reviews in Food Science and Nutrition 56.5 (2016): 871-884.

11. Auerbach B J., et al. "Fruit juice and change in bmi: A metaanalysis". Pediatrics 139.4 (2017).

12. Nicklas T A., et al. "Association between $100 \%$ juice consumption and nutrient intake and weight of children aged 2 to 11 years". Archives of Pediatrics and Adolescent Medicine 162.6 (2008): 557-565. 
13. O'Neil CE., et al. "Fruit juice consumption is associated with improved nutrient adequacy in children and adolescents: The nhanes 2003-2006". Public Health Nutrition 15.10 (2012): 1871-1878.

14. Murray R D. " $100 \%$ fruit juice in child and adolescent dietary patterns". Journal of the American College of Nutrition 39.2 (2020): 122-127.

15. O'Neil CE., et al. "Diet quality is positively associated with $100 \%$ fruit juice consumption in children and adults in the united states: Nhanes 2003-2006". Nutritional Journal 10.17 (2011): 1-10.

16. Clemens R., et al. "Squeezing fact from fiction about $100 \%$ fruit juice". Advances in Nutrition 6.2 (2015): 236S-243S.

17. Crowe-White K., et al. "Metabolic impact of $100 \%$ fruit juice consumption on antioxidant/oxidant status and lipid profiles of adults: An evidence-based review". Critical Reviews in Food Science and Nutrition 57.1 (2017): 152-162.

18. Auerbach B J., et al. "Review of $100 \%$ fruit juice and chronic health conditions: Implications for sugar-sweetened beverage policy". Advances in Nutrition 9.2 (2018): 78-85.

19. Hebden L., et al. "Fruit consumption and adiposity status in adults: A systematic review of current evidence". Critical Reviews in Food Science and Nutrition 57.12 (2017): 2526-2540.

20. American academy of pediatrics: Committee on nutrition. "The use and misuse of fruit juice in pediatrics". Pediatrics 107.5 (2001): 1210-1213.

21. O'Neil C E., et al. "100\% orange juice consumption is associated with better diet quality, improved nutrient adequacy, decreased risk for obesity, and improved biomarkers of health in adults: National health and nutrition examination survey, 2003-2006". Nutritional Journal 11 (2012): 107.

22. Wang Y., et al. "Impact of orange juice consumption on macronutrient and energy intakes and body composition in the us population". Public Health Nutrition 15.12 (2012): 2220-2227.
23. Yang M., et al. "Orange juice, a marker of diet quality, contributes to essential micronutrient and antioxidant intakes in the united states population". Journal of Nutrition Education and Behavior 45.4 (2013): 340-348.

24. Rampersaud GC and M F Valim. “100\% citrus juice: Nutritional contribution, dietary benefits, and association with anthropometric measures". Critical Reviews in Food Science and Nutrition 57.1 (2017): 129-140.

25. Simpson E J., et al. "Orange juice consumption and its effect on blood lipid profile and indices of the metabolic syndrome; a randomised, controlled trial in an at-risk population". Food Function 7.4 (2016): 1884-1891.

26. Papandreou D., et al. "Consumption of raw orange, $100 \%$ fresh orange juice, and nectar- sweetened orange juice-effects on blood glucose and insulin levels on healthy subjects". Nutrients 11.9 (2019).

27. Papandreou D and E Magriplis. "Consumption of raw orange, $100 \%$ fresh orange juice, and nectar- sweetened orange juiceeffects on blood glucose and insulin levels on healthy subjects". Nutrients 11.9 (2019).

28. Xi B., et al. "Intake of fruit juice and incidence of type 2 diabetes: A systematic review and meta-analysis". PLoS One 9.3 (2014): e93471.

29. Scheffers F R., et al. "Pure fruit juice and fruit consumption and the risk of cvd: The european prospective investigation into cancer and nutrition-netherlands (epic-nl) study". British Journal of Nutrition 121.3 (2019): 351-359.

30. Wang Y., et al. "Effects of chronic consumption of specific fruit (berries, citrus and cherries) on cvd risk factors: A systematic review and meta-analysis of randomised controlled trials". European Journal of Nutrition (2020).

31. Aptekmann N P and T B. César. "Long-term orange juice consumption is associated with low ldl-cholesterol and apolipoprotein $\mathrm{b}$ in normal and moderately hypercholesterolemic subjects". Lipids and Health Disease 12 (2013): 119. 
32. Busing F., et al. "High intake of orange juice and cola differently affects metabolic risk in healthy subjects". Clinical Nutrition 38.2 (2019): 812-819.

33. Morand C., et al. "Hesperidin contributes to the vascular protective effects of orange juice: A randomized crossover study in healthy volunteers". American Journal of Clinical Nutrition 93.1 (2011): 73-80.

34. Oude Griep L M., et al. "Association of raw fruit and fruit juice consumption with blood pressure: The intermap study". American Journal of Clinical Nutrition 97.5 (2013): 1083-1091.

35. Lee S G., et al. "Impact of orange juice consumption on bone health of the u.S. Population in the national health and nutrition examination survey 2003-2006". Journal of Medicinal Food 17.10 (2014): 1142-1150.

36. Kean R J., et al. "Chronic consumption of flavanone-rich orange juice is associated with cognitive benefits: An 8-wk, randomized, double-blind, placebo-controlled trial in healthy older adults". American Journal of Clinical Nutrition 101.3 (2015): 506-514.

37. Bedford, E. "Orange juice domestic consumption in the united states from 2008/09 to 2019/20". Statista (2020).

38. Ahluwalia N., et al. "Update on nhanes dietary data: Focus on collection, release, analytical considerations, and uses to inform public policy". Advances in Nutrition 7.1 (2016): 121134.

39. Centers for Disease Control and Prevention and National Center for Health Statistics. "National health and nutrition examination survey, survey methods and analytic guidelines" (2020).

40. National Health and Nutrition Examination Survey. "Mec inperson dietary interviewers procedures manual pdf" (2002).

41. Centers for Disease Control and Prevention. "Nchs research ethics review board (erb) approval" (2017).
42. Centers for Disease Control and Prevention and National Center for Health Statistics. "National health and nutrition examination survey (nhanes), response rates and population totals" (2020).

43. "National health and nutrition examination survey (nhanes) analytic and reporting guidelines" (2020).

44. National health and nutrition examination survey (nhanes). "Questionnaires, datasets, and related documentation" (2020).

45. Nhanes. "Documentation, codebooks, sas code" (2020).

46. National health and nutrition examination survey. "Anthropometry procedures manual pdf" (2020).

47. National Heart, Lung, and Blood Institute. "Overweight and obesity" (2020).

48. United States Department of Agriculture and Agricultural Research Service. "Usda food and nutrient database for dietary studies" (2019).

49. National Center for Health Statistics. "The nhanes $2002 \mathrm{mec}$ in-person dietary interviewers procedures manual" (2002).

50. U S Department of Agriculture. "What we eat in america/ nhanes overview". Food Surveys Research Group October (2019).

51. National Cancer Institute. "Usual dietary intakes: The nci method". Epidemiology and Genomics Research Program (2020).

52. Dietary reference intakes: Applications in dietary assessment. Washington, DC: The National Academies Press (2000).

53. Moore L V and F E Thompson. "Adults meeting fruit and vegetable intake recommendations - united states, 2013". MMWR Morbidity and Mortality Weekly Report 64.26 (2015): 709-713.

54. Vance V A., et al. "Self-reported dietary energy intake of normal weight, overweight and obese adolescents". Public Health Nutrition 12.2 (2009): 222-227. 
55. Rennie K L., et al. "Secular trends in under-reporting in young people”. British Journal of Nutrition 93.2 (2005): 241-247.

56. Briefel R R., et al. "Dietary methods research in the third national health and nutrition examination survey: Underreporting of energy intake". The American Journal of Clinical Nutrition 65.4 (1997): 1203S-1209S.

57. Champagne C M., et al. "Underreporting of energy intake in biracial children is verified by doubly labeled water". Journal of the American Dietetic Association 96.7 (1996): 707-709.

\section{Assets from publication with us}

- Prompt Acknowledgement after receiving the article

- Thorough Double blinded peer review

- Rapid Publication

- Issue of Publication Certificate

- High visibility of your Published work

Website: www.actascientific.com/

Submit Article: www.actascientific.com/submission.php

Email us: editor@actascientific.com

Contact us: +919182824667 